Data de Depósito:

Assinatura:

\title{
Ambiente de Programação de Robôs Móveis
}

Sérgio Ricardo Godinho Salazar

Orientador: Prof. Dr. Eduardo do Valle Simões

Dissertação apresentada ao Instituto de Ciências Matemáticas e de Computação - ICMC-USP, como parte dos requisitos para obtenção do título de Mestre em Ciências - Ciências de Computação e Matemática Computacional.

USP - São Carlos

Fevereiro/2008 
Dedico este trabalho às pessoas que têm sido motivo do meu crescimento humano e edificação moral: Minha família. 


\section{Agradecimentos}

Gostaria acima de tudo agradecer ao Deus verdadeiro e justo que me proporcionou no decorrer da minha vida acadêmica, muitas oportunidades me apresentando pessoas maravilhosas, sabiamente selecionadas para concretizar mais essa realização.

À minha mãe, que frente as dificuldades que o trabalho impunha e a minha labuta em tentar transpassá-los não se limitou em me apoiar emocionalmente e inúmeras vezes financeiramente, se fazendo presente em todos os momentos.

Aos meus irmãos, pela compreensão e carinho que dedicaram abrindo mão do conforto de casa fazendo trabalhos escolares e de faculdade na biblioteca para me ceder a pequena medida de paz que todos buscamos na confecção de uma dissertação.

Aos meus amigos que me apoiaram, Mauro Miazaki, Bruno Ferrez e principalmente ao Victor Hugo Vieira que conviveu bastante com minhas alterações de humor e soube com muita disciplina discernir meu comportamento.

Ao prof. Dr. Eduardo do Valle Simões, que contribuiu com idéias para esse trabalho, incentivando a pesquisa com artigos em congressos, exposições, feiras se dedicando não apenas como orientador, virando madrugadas, corrigindo artigos, soldando circuitos, programando, mas como amigo, em churrascos, passeios, competições de arco e flecha e principalmente em suporte humano.

À Liane e sua filha Luísa que por muitas madrugadas, fins de semana e feriados abdicaram da presença do marido e pai que se dedicava ao seu orientado.

Gostaria de agradecer ao Grupo de Sistemas Embarcados Evolutivos e Robóticos (SEER) do Departamento de Sistemas de Computação do Instituto de Ciências Matemáticas e Computação (ICMC) pela ajuda em tantas coisas e aos seus integrantes Felipe Navas, Rodrigo Marchesini, Vitor Boschi, Thiago (Babu).

Aos amigos de longas datas Antonio Luis Improise, Hercules Benício, Leonardo Salemi pela compreensão da minha ausência.

Por fim sou extremamente grato à Leízza Ferreira Rodrigues, minha noiva, e a minha família pela paciência amor e apoio. Sem eles, de forma alguma teria chegado até aqui! Também sou grato a Deus, meu consolador, quem esteve sempre presente me dando domínio próprio e que nos momentos difíceis alegrou meu coração me fazendo lembrar do seu amor e zelo por mim. 


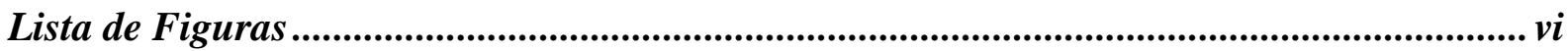

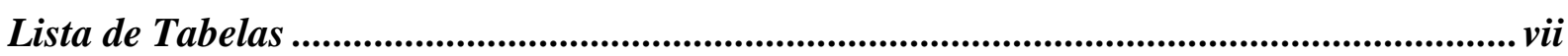

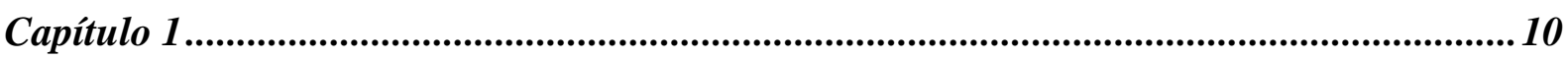

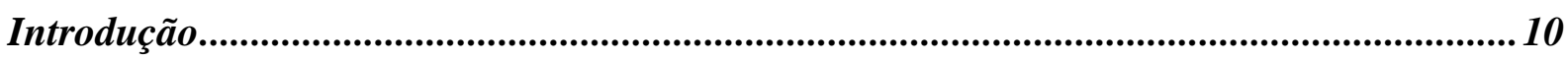

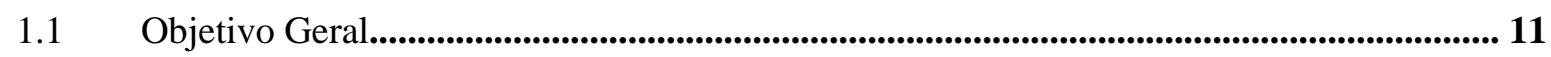

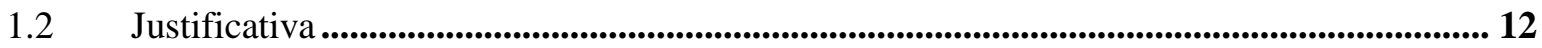

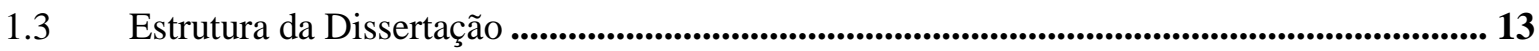

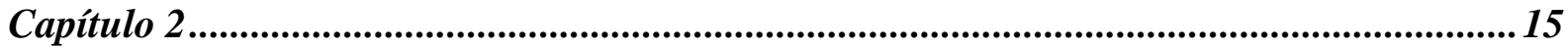

Análise e Projeto do Sistema .................................................................................................... 15

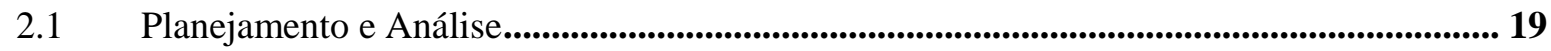

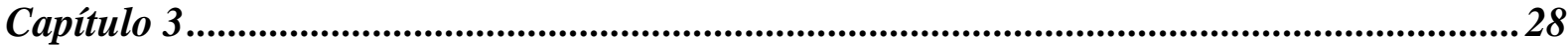

Ambiente de Programação de Robôs Móveis ...............................................................................28

3.1 Internacionalização do Software............................................................................................. 29

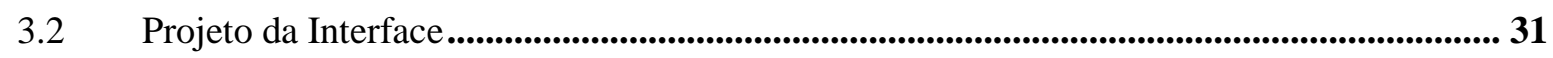

3.3 Portabilidade para Plataformas Windows e Linux.............................................................. 32

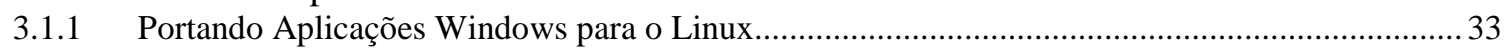

3.4 Migração de Software do Windows para Linux ............................................................................ 34

3.5 Linguagens Formais e Compiladores.................................................................................................. 37

3.6 Projeto da Linguagem de Programação do Robô ......................................................................... 38

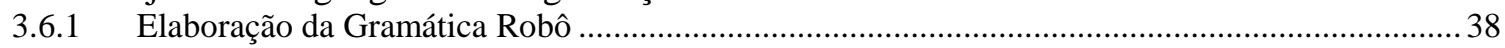

3.7 Desenvolvimento do Compilador para a Gramática Robô ......................................................39

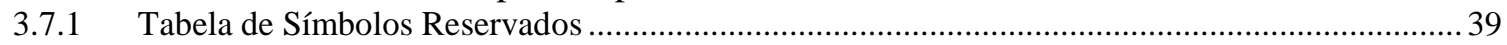

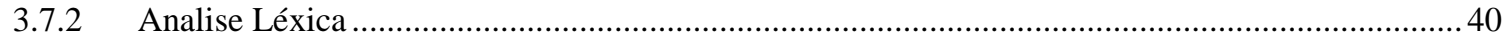

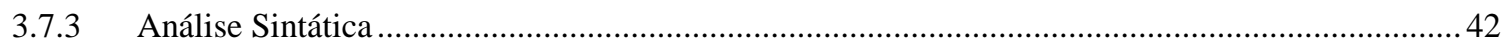

3.8 Desenvolvimento do Módulo Blocos.................................................................................... 44

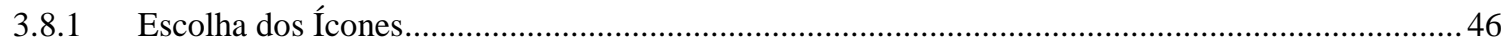

3.8.2 Implementação das Técnicas para manipulação de blocos .............................................................. 48

3.8.3 Implementações das Técnicas para Salvar e Abrir Blocos .............................................................49

3.8.4 Aperfeiçoamento da Gramática do Robô................................................................................... 50

3.9 Desenvolvimento dos Módulos C e Assembly ......................................................................52

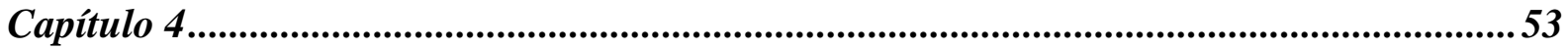

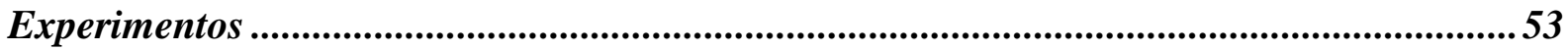

$4.1 \quad$ Experimento 1: Escolas Públicas ..................................................................................................5 53

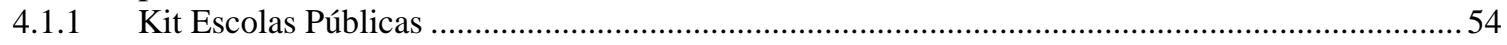

4.2 Experimento 2: Laboratório de Robótica a Distância................................................................5 58

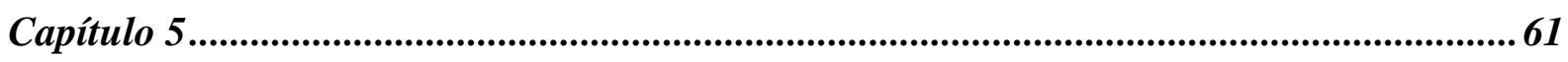

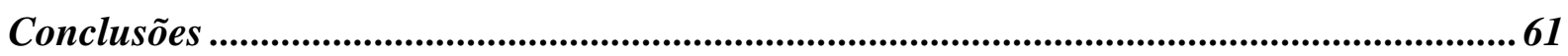




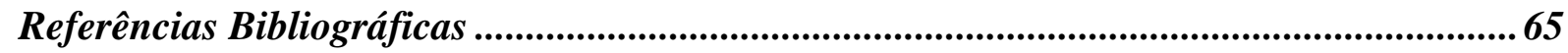




\section{Lista de Figuras}

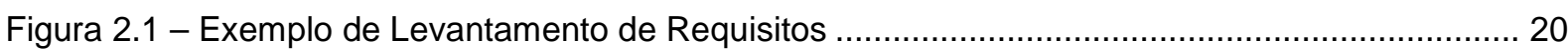

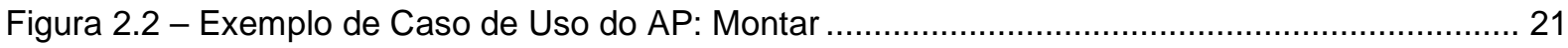

Figura 2.3 - Exemplo de Diagrama de Caso de Uso: Diagrama parcial ............................................ 22

Figura 2.4 - Exemplo de Diagrama de Classe Conceitual para o Caso de Uso: Criar um programa

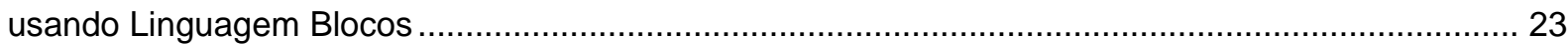

Figura 2.5 - Exemplo de Diagrama de Seqüência para o Caso de Uso: Criar um programa usando

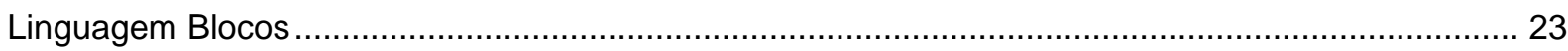

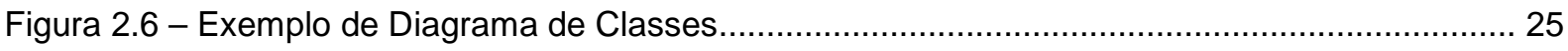

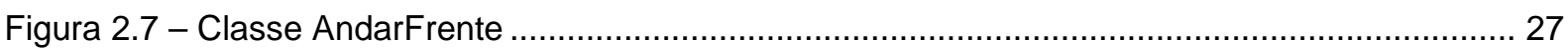

Figura 3.1 - Ambiente de programação com os idiomas suportados................................................ 30

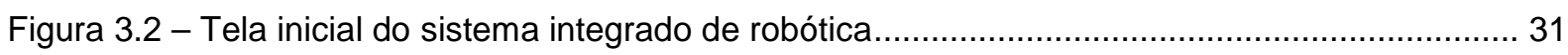

Figura 3.3 - Aplicação MDI com alternação de janelas................................................................ 32

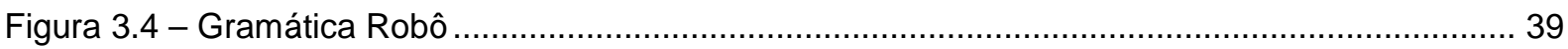

Figura 3.5 - Autômato Finito representando os passos do Analisador Léxico para a Gramática

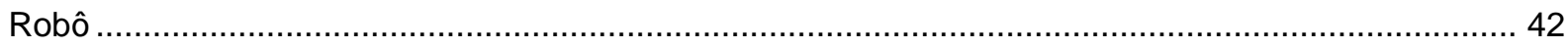

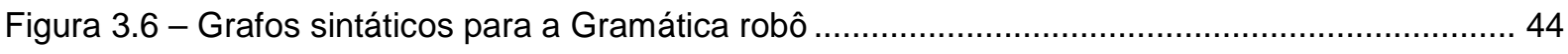

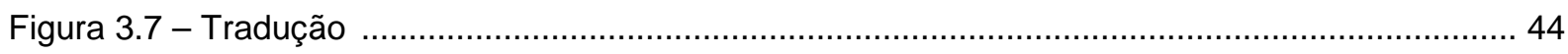

Figura 3.8 - Mensagem de advertência disparada pelo compilador ................................................ 46

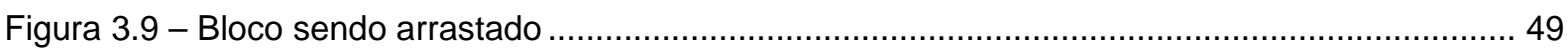

Figura 4.1 - Robô móvel autônomo de médio porte ........................................................................... 55

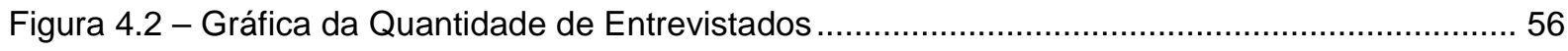

Figura 4.3 - Gráfico da Escolaridade dos Entrevistados ............................................................ 56

Figura 4.4 - Gráfica com dados referente ao interesse do usuário em Robótica ............................... 57

Figura 5.1 - Protótipo da Interface de Programação do LRD: interface padrão .................................. 63 


\section{Lista de Tabelas}

Tabela 2.1 - Caso de teste com os valores válidos e inválidos para o atributo $x$ em sua restrição $\{>=-32768\}$ 27

Tabela 3.1 - Técnicas de transferência . 34

Tabela 3.2 - Tabela de Símbolos Reservados da Gramática Robô..................................................... 40

Tabela 3.3 - Tabela com a descrição dos ícones utilizados na programação blocos.......................... 47

Tabela 4.1 - Opinião sobre ter robôs como ferramenta pedagógica................................................. 56

Tabela 4.2 - Dados apresentados o que o usuário mais gostou nos robôs.......................................... 57 


\section{Resumo}

Este trabalho propõe um Ambiente de Programação de Robôs Móveis direcionado especialmente à língua portuguesa, que consiste em um novo ambiente de programação gráfica e textual, capaz de atender a perfis diferenciados de usuários. O ambiente de programação contém três módulos para programação de robôs móveis: o modulo C ou editor C, o módulo Assembly ou editor Assembly, e o módulo blocos que é um módulo que contêm blocos de programação para auxiliar os programadores inexperientes a programarem robôs móveis por meio de uma meta linguagem desenvolvida que encapsula a linguagem $\mathrm{C}$. $\mathrm{O}$ diferencial deste trabalho consiste na Gramática adaptativa criada para robôs móveis, que é uma derivação das gramáticas descendentes recursivas com um mecanismo de busca ("look ahead"). A derivação encontra-se na definição formal de gramática que foi adaptada nessa proposta para permitir a categorização de terminais da gramática, adicionando um passo a mais na compilação, que é a checagem de categorias permitidas da linguagem. Nesta dissertação são relacionados alguns ambientes de programação de robôs disponíveis na literatura bem como uma discussão de suas características. Também são apresentados experimentos realizados com usuários não especializados em programação, principalmente crianças, e com o Laboratório de Robótica a Distância da Universidade de São Paulo em São Carlos, São Paulo.

Palavras-chave: ambiente de programação, robôs móveis. 


\section{Abstract}

This work proposes a Mobile Robot Programming Environment focused in the Portuguese language, which is able to attend different user categories and where the user can work textually and graphically. The programming environment contains three different modules: the $\mathrm{C}$ module, or $\mathrm{C}$ editor; the Assembly module, or Assembly editor; and the block module, which contains programming blocks that can help novice programmers to develop software for mobile robots using a meta-language that encapsulates the $\mathrm{C}$ language. The major contribution of this work consists of the proposition of a novel adaptive grammar, specially developed to mobile robots, which is a derivation of recursive descendent grammars, containing a look ahead module. The derivation is found in the formal definition of the grammar, adapted to allow the specification of grammar terminals, adding one more compilation step, which is the check of language permitted categories. The document presents some robot programming environments found in literature and discusses their characteristics. The results show experiments performed with non-specialized users, mostly children, and with the Remote Robotics Laboratory of the University of São Paulo, in São Carlos, São Paulo state, Brazil.

Key-words: programming environment, mobile robots 



\section{Capítulo 1}

\section{Introdução}

Um robô móvel é um agente artificial com capacidade de locomoção e capaz de atuar em um ambiente, de modo racional e não passivo [14]. Em constraste, os robôs industriais geralmente são formados por um braço articulado e um dispositivo de atuação, presos a uma superfície fixa. Ambos necessitam, porém, de um sistema para sua programação, seja automática ou manual. A programação manual necessita que um programador defina as tarefas a serem executadas e enviadas ao robô. Normalmente esse tipo de programação é chamada off-line porque o robo nao está presente enquanto é criada a programação.

Em 1973 foi criada a primeira linguagem de programação para robôs móveis chamada Wave pelo SRI [2]. Foi seguida pela AL em 1974 pelo mesmo grupo feita em ALGOL [3]. A linguagem de robôs WAL foi a primeira linguagem comercial, desenvolvida por Victor Scheinman e Bruce Simano para a Unimation Inc. Posteriormente surgiram outras linguagens para programação textual de robôs. Porém, a programação textual exigia familiaridade com a linguagem de programação e com as primitivas de hardware (funções de baixo nível entre o software e o hardware), bem como, os comandos diretos, portas lógicas e físicas, e o hardware formado por CI's (circuitos impressos).

Mais recentemente surgiram alguns ambientes de programação que passaram a disponibilizar uma interface gráfica amigável. Nos anos 90 surgiram o LabVIEW[4], o KTProject, que já é um ambiente específico para robôs Khepera [5][19], e o Robolab [6][20]. Em 2006 surgiram o kit robótico chamado Lego Mindstorms NXT [7] em substituição à primeira geração do kit Lego Mindstroms e o Microsoft Robotics Studio 1.0, um ambiente destinado a criar aplicações robóticas[1]. Em 2007 foram lançados na Carnegie Mellon 
University o TeRK (kit Telepresence Robô) [8] e a versão beta-teste da linguagem RobotC [9] [10], uma derivação da famosa linguagem C.

Todos esses ambientes de programação e/ou desenvolvimento podem ser utilizados para programação de inúmeros robôs disponíveis no mercado internacional, por exemplo, Braintech, Camelot Robotics, Cerebellum, Graupner, Hanulkid, InTouch Health, MicroInfinity, Mostitech, RidgeSoft, Robo3, VIA Technologies e a Yujin Robot. Entretanto, a utilização desses ambientes de programação é restrita ao ambientes de pesquisa e estudo no Brasil, uma vez que não existem no mercado produtos nacionais que supram a demanda de software com código aberto, e os usuários dependem tanto da importação do robô quanto do pagamento pela licença de uso do software para uso comercial.

Inspirado na combinação desses dois problemas, e na necessidade de desenvolvimento de um software aberto para programação de robôs móveis nacionais, este trabalho propõe a criação de um ambiente de programação tanto gráfica, quanto textual-português, para robôs móveis. Para isso, serão relacionados e discutidos os ambientes mais comuns encontrados na literatura para que possam ser comparados ao ambiente proposto.

\subsection{Objetivo Geral}

O objetivo deste trabalho é propor um ambiente para programação gráfica e textual de robôs móveis autônomos. Através deste ambiente, pode-se utilizar três formas de programar os robôs: programação em linguagem Assembly, em linguagem C ou através de uma metalinguagem, aqui denominada Linguagem Blocos. $\mathrm{O}$ ambiente proposto nesse trabalho contém um módulo de programação em blocos com ícones auto-explicativos para facilitar a programação dos robôs por usuários inexperientes. O ambiente de programação também utiliza uma estratégia diferenciada de compilação para permitir que o programa gerado seja independente da arquitetura do robô, ou seja, na solução desse requisito definiu-se uma gramática que possibilita a programação de robôs com hardware ou arquitetura distintos. 
Este trabalho se encontra dentro do contexto do projeto Laboratório de Robótica a Distância, com financiamento do CNPq, desenvolvido no Laboratório de Robótica Móvel do Grupo de Sistemas Embarcados Evolutivos e Robóticos (SEER) do Departamento de Sistemas de Computação do Instituto de Ciências Matemáticas e Computação (ICMC) da Universidade de São Paulo (USP) em São Carlos. Esse laboratório de robótica a distância permite o acesso via internet de seus robôs mediante agendamento por estudantes de universidades públicas. O ambiente de programação proposto neste trabalho está inserido dentro desse projeto como uma ferramenta de apoio ao usuário do laboratório, que poderá fazer o download do ambiente para desenvolver programas localmente em sua máquina e depois agendar pelo site do Laboratório de Robótica um horário para executar seus experimentos nos robôs disponíveis.

\subsection{Justificativa}

Atualmente, existem várias abordagens que tratam a questão de programação de robôs móveis. Neste caso, um dos problemas é a dificuldade em se programar um robô em um ambiente que trabalhe na língua portuguesa, capaz de atender a perfis diferenciados de usuários, utilizando conceitos da área pedagógica, fornecendo uma ferramenta de programação a alunos e professores dos setores público e privado (área educacional e de pesquisa), além de aplicações domésticas.

Outro problema é o fato de grande parte dos softwares disponíveis necessitarem de licença de uso para fins comerciais. Nos dois casos nota-se que o maior desafio é produzir um software nacional para plataformas robóticas nacionais, que tenha código fonte aberto, que seja flexível e robusto, permitindo a programação de diferentes robôs de diferentes arquiteturas, e que possua uma interface amigável, facilitando o trabalho do usuário na tarefa de criar um programa para ser embarcado em um robô móvel autônomo. 
No Brasil, o desenvolvimento de projetos na área de robótica encontra inúmeras dificuldades devido aos altos custos de importação e manutenção dos produtos estrangeiros. Existem empresas e universidades no país que chegaram a adquirir robôs importados e, posteriormente, não tiveram suporte técnico adequado ou acesso a peças de reposição, ocasionando a perda do investimento [40][41].

Como a área de robótica está em constante evolução, os equipamentos ficam obsoletos rapidamente devido à falta de manutenção, fazendo com que o investimento tenha uma baixa relação custo-benefício. Dessa forma, devido às dificuldades de aquisição e de suporte para robôs móveis estrangeiros, a popularização de sistemas robóticos no país encontra-se muito atrasada em relação ao primeiro mundo [40][42]. Para que essas dificuldades sejam abordadas é necessário que sejam desenvolvidas pesquisas de maneira a difundir o uso de robôs móveis em escolas, na medicina, engenharia, física e tantas outras áreas. E é neste contexto que este trabalho visa contribuir com a proposta de um ambiente de programação de robôs versátil, de código aberto e interface com o usuário em português.

\subsection{Estrutura da Dissertação}

Este trabalho propõe um novo ambiente para programação gráfica e textual de robôs móveis. A descrição dos procedimentos para a obtenção deste ambiente está exposta nos capítulos que se seguem, estruturados da seguinte forma:

No Capítulo 2, é apresentada a Análise de Software e suas etapas em UML. A cada etapa desenvolvida é colocado um exemplo de diagrama ou de artefato correspondente.

No Capítulo 3, é detalhado o Ambiente de Programação de Robôs móveis, incluindo sua Gramática que é o diferencial deste trabalho.

No Capítulo 4, são apresentados o conjunto de experimentos realizados em um Laboratório de Robótica e em Escolas Públicas, e a análise de seus resultados. 
No Capítulo 5, são apresentadas as conclusões, formuladas a partir dos resultados dos experimentos, e são propostas sugestões de trabalhos futuros. 


\section{Capítulo 2}

\section{Análise e Projeto do Sistema}

O primeiro robô móvel foi desenvolvido em 1968 pelo Stanford Research Institute (SRI) e chamava-se Shakey [15]. Nos últimos anos essa tecnologia vem sendo aplicada no desenvolvimento de robôs domésticos e de brinquedos educativos [14]. Recentemente, surgiram alguns ambientes de programação que passaram a disponibilizar uma interface gráfica amigável. Em 1986 surgiu O LabVIEW (Laboratory Virtual Instrument Engineering Workbench) [4], uma linguagem de programação gráfica pertencente à National Instruments, inicialmente para máquinas Macintosh e posteriormente para Windows, Linux e Solaris. Os programas LabVIEW são chamados de Instrumentos Virtuais (IV) e são compostos por uma interface e um bloco de diagramas. O programa não é lido por um intérprete, mas sim compilado. O fluxo de dados é conseguido a partir da conexão de linhas de ligação (wires) entre os instrumentos virtuais. Devido ao princípio do fluxo de dados, as chamadas recursivas não são possíveis, podendo-se no entanto conseguir esse efeito usando artifícios.

Em 1993 foi criado o KTProject ambiente específico para robôs Khepera [5][19]. Ele possui uma interface gráfica para ambiente Windows desenvolvida pelo próprio fabricante do robô e permite que programas desenvolvidos em C sejam compilados e gravados diretamente na memória do Khepera, permitindo que o mesmo execute tarefas em modo autônomo. Softwares comerciais como o LabVIEW® e o MATLAB® possuem bibliotecas específicas para o Khepera e permitem o desenvolvimento de aplicações mais complexas, porém, limitando a área de atuação do robô, já que o mesmo permanece conectado ao cabo serial que liga o robô ao PC. 
Em 1998 foi lançada a linha LEGO Mindstorms [12] que é uma linha do briquedo LEGO. Seu ambiente de programação gráfica é o Robolab [6][20] que foi desenvolvido pela Tufts University com base no LabWIEW, da National Instruments, para controlar o tijolo programável Robotic Command Explorer (RCX). O Robolab foi desenvolvido como um programa educacional, especialmente para professores e adultos, para ser trabalhado com grupos de crianças e dispositivos robóticos LEGO. O programa é baseado em ícones, permitindo aos educandos visualisarem as instruções que estão seguindo conjuntamente na construção de seus robôs. O programa contém níveis de programação básico, intermediário e avançado, incluindo geração de relatórios de dados.

Em julho de 2006 foi criado um kit robótico chamado Lego Mindstorms NXT [7] em substituição à primeira geração de kit Lego Mindstroms. O kit é equipado com um processador potente, software próprio e sensores de luz, de toque e de som, permitindo a criação, programação e montagem de robôs com noções de distância, capazes de reagir a movimentos, ruídos e cores, e de executar movimentos com razoável grau de precisão. Os novos modelos permitem que se criem não apenas estruturas, mas também comportamentos, permitindo a construção de modelos interativos, com os quais se aprendem conceitos básicos de ciência e de engenharia.

Em dezembro de 2006 a Microsoft lançou o Microsoft Robotics Studio 1.0 [1], um ambiente destinado a criar aplicações robóticas. Este software de desenvolvimento baseado no Windows permite criar programas de robótica para uma ampla variedade de plataformas de hardware. Além disso, conta com uma linguagem de programação visual que oferece aos utilizadores a possibilidade de programar robôs utilizando um ambiente orientado por objetos, uma ferramenta 3D que simula aplicações robóticas em ambientes virtuais que obedecem às leis da física e uma rotina de execução em tempo real que permite às aplicações se comunicarem com o hardware. 
O Robotic Studio permite o desenvolvimento de aplicações utilizando um conjunto de linguagens de programação que incluem o Microsoft Visual Studio e o Microsoft Visual Studio Express (Visual C\# e Visual Basic), além do Microsoft IronPython. O Microsoft Robotics Studio é compatível com as aplicações, serviços e robôs de empresas como a CoroWare, iRobot, KUKA Robot Group, the LEGO Group, Parallax, RoboDynamics, Robosoft, RoboticsConnection, Senseta, Sharp Logic ou Surveyor, entre outras. Além disso, muitas outras empresas inscreveram-se no Programa de Sócios da Microsoft Robotics Studio para lançarem aplicações e robôs compatíveis no futuro, entre as quais se contam a Braintech, Camelot Robotics, Cerebellum, Graupner, Hanulkid, InTouch Health, MicroInfinity, Mostitech, RidgeSoft, Robo3, VIA Technologies e a Yujin Robot. Os apreciadores, estudantes e universitários podem utilizar este software sem qualquer custo. Os criadores de robôs comerciais podem legalizar a utilização desta plataforma de desenvolvimento pelo valor mínimo de 304 euros (estimado em novembro de 2007).

Em abril de 2007 foi lançado na Carnegie Mellon University o TeRK (kit Telepresence Robô) [8]. Ele é um kit robótico formado por um controle único chamado de Qwerk que combina um computador com o software e eletrônicos necessários para controlar os motores do robôs, câmeras e outros dispositivos. Foi desenvolvido por Illah Nourbakpois, professor de robótica, em conjunto com uma equipe do laboratório Community Robotics, Education and Technology Empowerment e contou com o apoio do Google, da Microsoft e da Intel. O sistema é Linux, podendo ser utilizado qualquer linguagem de programação para controle do robô.

O Qwerk, desenvolvido pelos laboratórios CREATE e Charmed (de Austin, no Texas), também conecta o robô à Internet sem fio - dessa forma, ele pode ser controlado por qualquer computador conectado à rede. O ambiente de programação do TeRK é o Express-O-Matic, uma interface gráfica que permite a programação similar a do Flower Power, porém inclui 
diferentes condições pré-definidas e é projetado para ser genérico o bastante para qualquer robô TeRK. O Flower Power é também uma interface gráfica que mostra o robô no formato de uma flor. O Qwerk também pode ser programado usando o MS Robotics Studio.

A Universidade Carnegie Mellon também lançou em julho de 2007 a versão beta-teste da linguagem RobotC [9] [10], uma derivação da famosa linguagem C. Ela foi criada especialmente para atender às necessidades de programação textual dos circuitos lógicos e elétricos dos robôs. A RobotC já foi testada para a programação de microcontroladores existentes em vários kits disponíveis comercialmente, como os da série Lego Mindstorms.

A URBI (Universal Real-time Behaviour Interface) [13] é uma plataforma open source que permite controlar qualquer robô ou sistema complexo como um video game, usando uma linguagem script que pode ser interfaceada com várias linguagens de programação $(\mathrm{C}++$, Java, Matlab) e sistemas operacionais como (Windows, Mac OSX, Linux). O URBI é baseado numa arquitetura cliente/servidor e permite soluções como execução de comandos em paraleto, programação baseada em eventos, command tagging e variáveis dinâmicas. Atualmente, URBI é usado tanto em laboratórios de pesquisa, quanto na indústria e por usuários de robótica.

Segundo os conceitos de Análise e desenvolvimeno de software uma disciplina da engenharia de sofware o desenvolvimento dos ambientes de programação de robôs móveis, como os apresentados acima, pode ser realizada por meio de várias etapas: 1) Fase de Planejamento e Análise; 2) Fase de Codificação e 3) Fase de Testes. Portanto, o desenvolvimento deste projeto necessitou de uma revisão bibliográfica de alguns conceitos envolvendo essas etapas de desenvolvimento de sistemas. Além do estudo de ferramentas gráficas para programação, foi necessário o estudo de técnicas que tratam: de arquivos do sistema, do deslocamento de objetos na tela, da auto-criação de objetos na tela, da exclusão de 
objetos na tela; do compilador, etc. A seguir, são apresentados os estudos realizados dentro da fase de planejamento e análise das atividades do projeto.

\subsection{Planejamento e Análise}

Segundo Fritz Bauer [16], a Engenharia de Software é a utilização de sólidos princípios de engenharia para se construir software de maneira econômica, que seja confiável e que trabalhe eficientemente em máquinas reais. Genericamente, a Engenharia de Software envolve a análise, o projeto, a construção, a verificação e a gestão de elementos técnicos (ou sociais). Assim, ela é uma ferramenta metodológica para criação de um software, envolvendo para isso uma série de etapas, técnicas e notações associadas às etapas [18].

Entretanto, para facilitar o entendimento e a comunicação do produto final que será desenvolvido são criados modelos que descrevem o sistema. Uma ferramenta amplamente difundida é a UML (Unified Modeling Language - Linguagem Unificada de Modelagem), que é uma linguagem-padrão para a elaboração da estrutura de projetos de software [17]. Com ela, pode-se realizar a modelagem visual de maneira que os relacionamentos entre os componentes do sistema sejam melhor visualizados, compreendidos e documentados. Ela também permite especificar, construir, visualizar e documentar um sistema de software

Nesta sessão serão apresentadas as etapas utilizadas de Engenharia de Software para a criação do ambiente de programação, mostrando-se exemplos de cada etapa.

- Levantamento de Requisitos: nesse documento são descritas as funções do Ambiente de Programação (AP) de forma textual conforme mostra a Figura 2.1. Os requisitos englobam tanto a Interface Gráfica quanto à Interface de Comunicação. Neste exemplo são descritos como o ambiente deve se apresentar (amigavelmente) baseando-se em estudos de Usabilidade. Em seguida são descritos os componentes básicos que o ambiente deve conter, como programação em C e Assembly e programação em Blocos. A programação em Blocos deveria possuir algumas macros 
específicas para realizar movimento, para gerenciar os sensores e de inicialização do robô. Também, foi feito um esboço gráfico (protótipo) de Interface para melhor visualização de componentes.

- Disponibilizará a tela "Painel de Controle", que consiste no Programa Principal.

- Possuirá 3 módulos: Blocos, Linguagem C e Linguagem Assembly.

- Disponibilizará dois conjuntos de funções representadas por botões:

- Específica do Módulo de Blocos para gerenciamento do robô: andar, girar, curva, parar, tempo, led, sensor, liga, desliga.

- Específica do Painel de Controle: Novo (C, Blocos, Assembly), Abrir, Salvar, Salvar Como, Fechar, Configurar Impressão, imprimir, Sair, Desfazer, Refazer, Recortar, Copiar, Colar, Deletar, Selecionar Tudo, Localizar, Substituir, Modo de visualização, Joystick, Teclado, Consultar Status, Testar comunicação, Selecionar Porta Serial, Assistente de configuração, Ajuda do SIR, Sobre Sistema, Janelas (Em cascata, Lado a lado horizontalmente, Lado a lado verticalmente, Minimizar todas, Maximizar todas)

- Disponibilizará uma tela "Editor gráfico" para a Linguagem Assembly

- Disponibilizará uma tela "Editor gráfico" para a Linguagem C

- Disponibilizará modelos de programas com modelos fixos

- Criará um protocolo de comunicação que será associado às funções: estabelecer comunicação e enviar dados.

Figura 2.1 - Exemplo de Levantamento de Requisitos

- Casos de Uso: neste documento são apresentadas as descrições textuais das interações entre os atores (quem interage com o sistema) e as funções principais do software, a serem completadas pela aplicação. A Figura 2.2 mostra uma descrição textual do caso de uso Criar um programa usando Linguagem Blocos. Nessa descrição são explicados os objetivos dessa interação ator/sistema, quais são os atores e o cenário de sucesso principal que é o caminho típico ou otimista do cenário de sucesso [33]. Um caso de uso também pode ser representado sob a forma de um diagrama para ilustrar os nomes 
dos casos de uso e dos atores, bem como os relacionamentos entre eles. Na Figura 2.3

é apresentada uma parte do Diagrama Geral dos Casos de Uso do AP.

\section{Caso de Uso 1 : Criar um programa usando Linguagem Blocos}

Atores

Usuário Leigo, Usuário Médio e Usuário Avançado.

\section{Objetivos}

Permitir ao usuário leigo construir um programa de forma gráfica para controlar o robô. Permitir aos usuários médio e avançados programar em linguagem $\mathrm{C}$ e Assembly

\section{Pré-Condições}

- Um novo arquivo deve ser criado.

- Um arquivo existente deve ser aberto.

\section{Cenário de Sucesso Principal (Fluxo Básico)}

Um arquivo < nome $><$. ><extensão $>$ deve ser carregado.

Pelo menos um bloco deve ser arrastado para a Área de Blocos.

Se o bloco Andar for acionado deve ser escolhida a opção para <frente ou trás>

Se o bloco Girar for acionado deve ser escolhida a opção para <direita ou esquerda>

Se o bloco Curva for acionado deve ser escolhida a opção aciona roda < direita ou esquerda> com velocidade < nível> quando <condição inicial>

Se o bloco Parar for acionado deve ser escolhida a opção parar quando $<$ condição inicial > até que <condição final>

Se o bloco Tempo for acionado deve ser escolhida a opção temporizador $<$ nível> quando <condição inicial>

Se o bloco Led for acionado deve ser escolhida a opção acender led quando $<$ condição inicial> até que <condição final>

Se o bloco Sensor for acionado deve ser escolhida a opção sensor <número> Se o bloco Liga for acionado deve ser escolhida a opção liga <sem parâmetro>

O bloco é escolhido através de um clique no botão e um outro em seguida na Área de Blocos.

Se excluir bloco então

Excluir conector à esquerda e à direita

Conectar automaticamente bloco solto à lista

Se usuário colocar bloco em qualquer posição sobre um conector então

Conectar automaticamente bloco novo

Senão

Atualizar lista blocos

Ligar o novo bloco ao último bloco da lista

$\mathrm{O}$ arquivo $<$ nome $><$. $><$ extensão $>$ deve ser atualizado.

$\mathrm{O}$ arquivo $<$ nome $><$. $><$ extensão $>$ deve ser compilado.

$\mathrm{O}$ arquivo $<$ nome $><$. $><$ extensão $>$ deve ser enviado para o robô.

O ambiente deverá checar a ordem dos blocos, disponibilizando as macros para uso. Porém o uso será restrito a ordem da macro anterior, checando-se possíveis inconsistências.

Um código associado ao bloco é chamado a partir do clique do botão.

Figura 2.2 - Exemplo de Caso de Uso do AP: Montar 


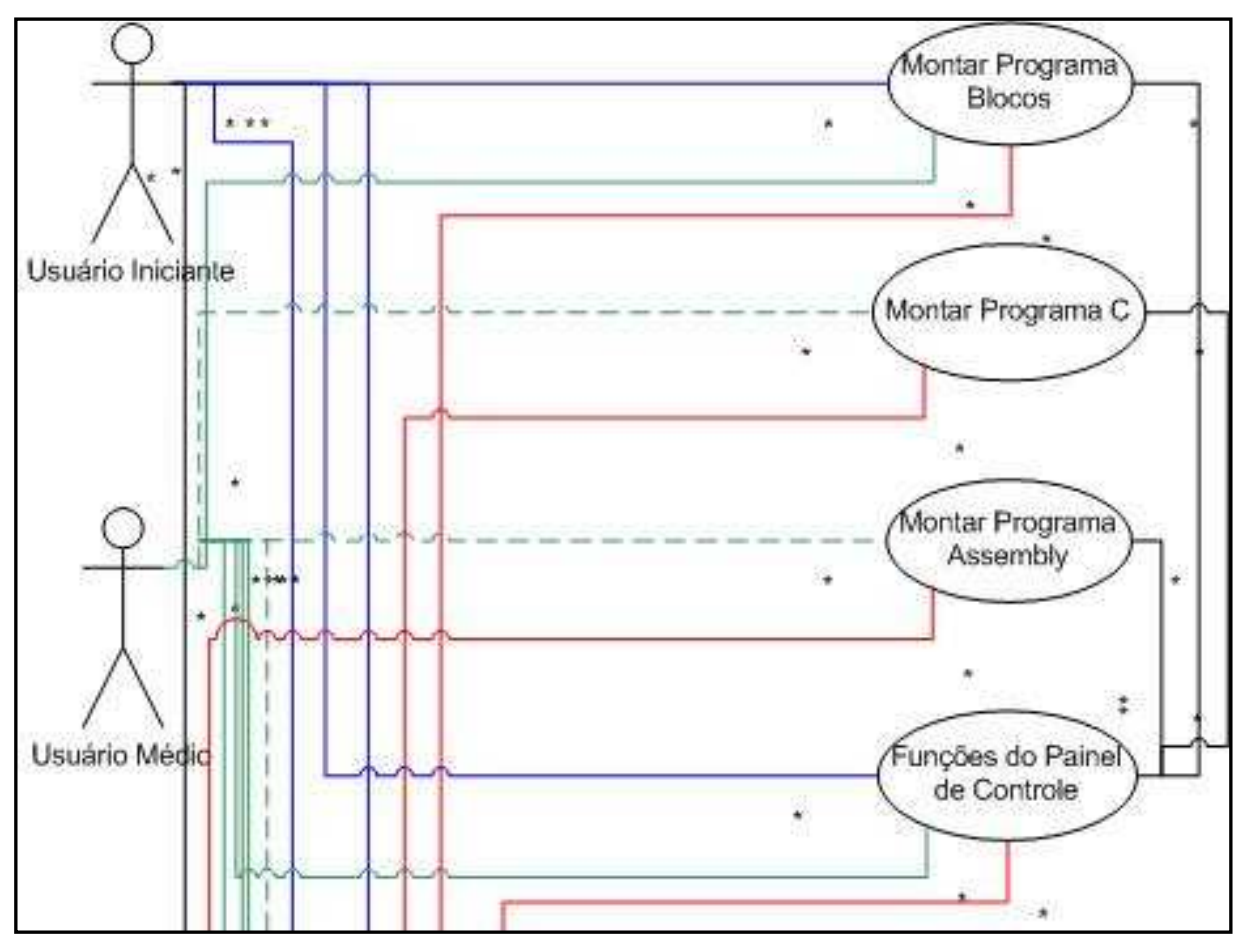

Figura 2.3 - Exemplo de Diagrama de Caso de Uso: Diagrama parcial

- Diagrama de Classes Conceitual: nesse documento são definidas as classes conceituais. De acordo com [33], as classes conceituais são “(...) uma idéia, uma coisa ou um objeto."; ou seja, são a visualização de um conceito do mundo real e não uma imagem de uma classe de software. Para sua criação foi utilizada a técnica proposta por [34] - Análise Lingüística, na qual todos os substantivos e frases nominais nas descrições textuais são considerados candidatos a classes conceituais ou atributos. A Figura 2.4 mostra um exemplo para o Caso de Uso da Figura 2.2. Do texto do caso de uso foram extraídos substantivos, alguns grifados em azul, como bloco. Neste caso foram extraídos vários tipos de blocos cujas informações importantes eram o seu tipo e sua posição $x-y$ na tela. 


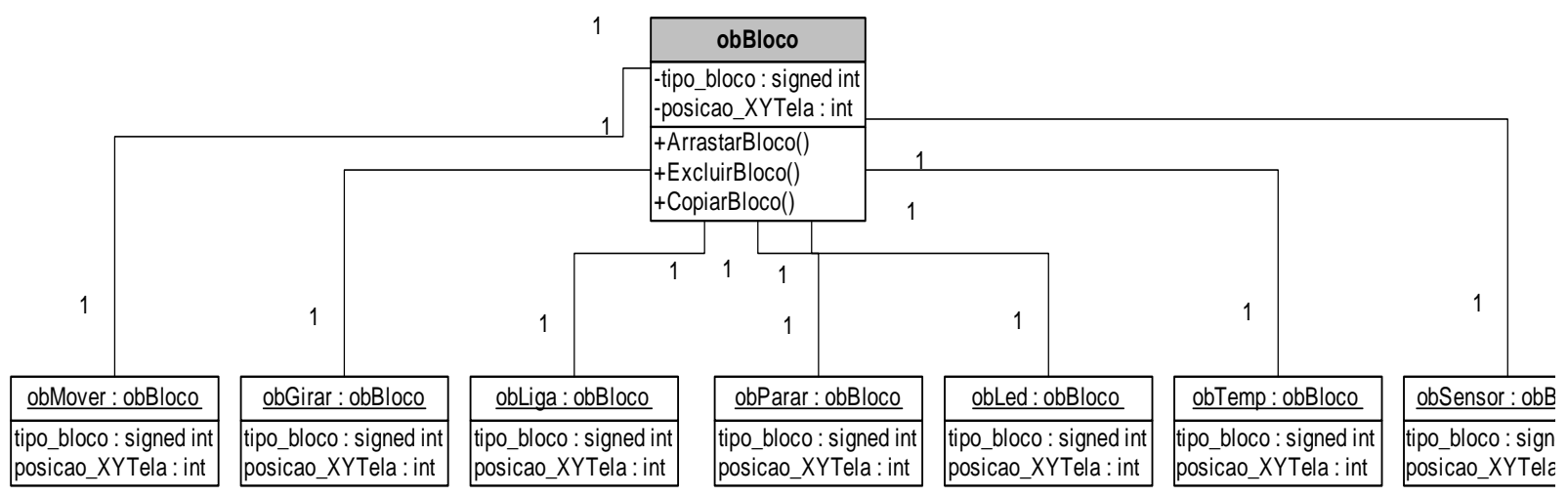

Figura 2.4 - Exemplo de Diagrama de Classe Conceitual para o Caso de Uso: Criar um programa usando

\section{Linguagem Blocos}

- Diagrama de Sequiência: nesse documento são criados diagramas (figuras) que mostram, para um cenário específico de um caso de uso, os eventos que os atores externos geram, sua ordem e os eventos entre os sistemas [33]. A Figura 2.5 mostra o Diagrama de Seqüência do Caso de Uso da Figura 2.2.

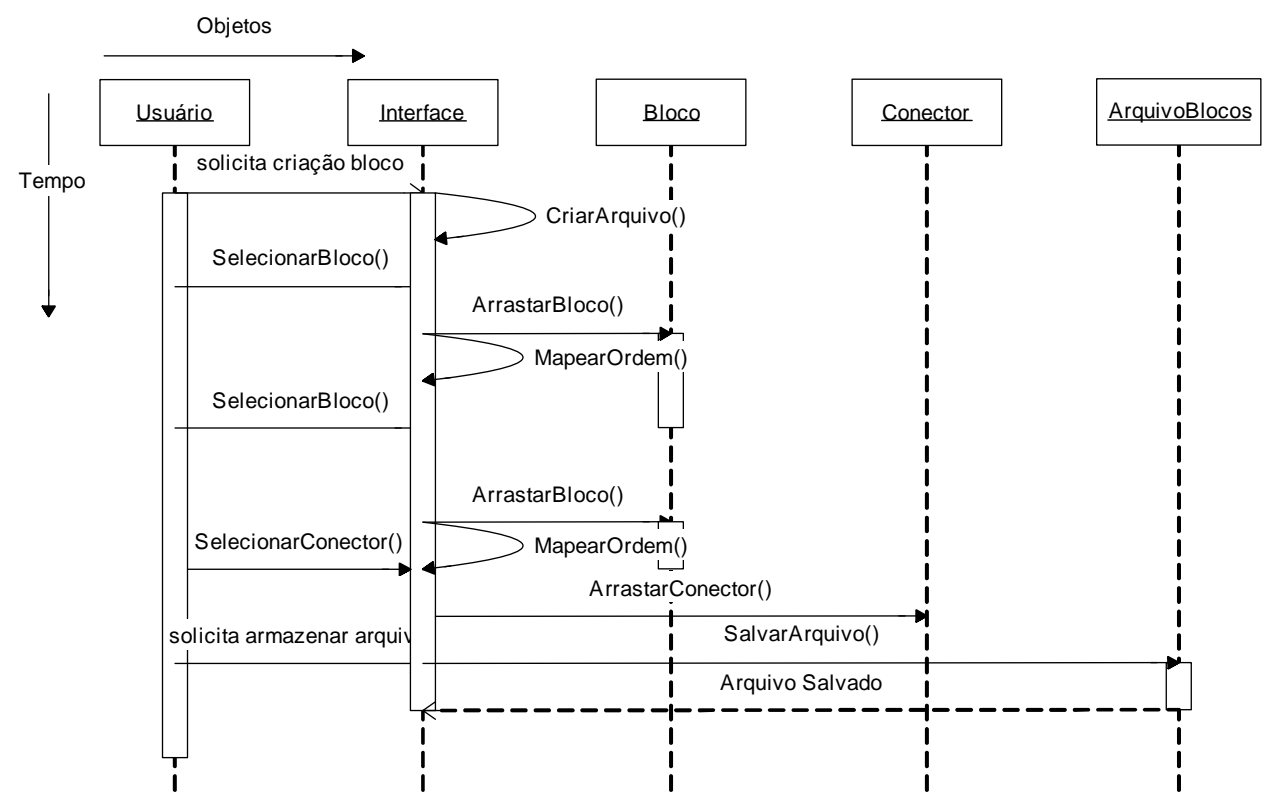

Figura 2.5 - Exemplo de Diagrama de Seqüência para o Caso de Uso: Criar um programa usando Linguagem Blocos

Na sequiência da figura 2.5, o usuário inicializa o sistema solicitando a criação de um arquivo bloco. A interface cria o arquivo. Em seguida o usuário seleciona um bloco, o bloco precisa ser arrastado dentro da interface e ter sua ordem mapeada. O usuário pode 
selecionar outros $n$ blocos e a interface se encarrega de conectá-los com uma linha. O usuário solicita salvar o arquivo, o sistema grava-o em disco.

- Diagrama de Classes: neste documento são descritas as classes estáticas do sistema obtidas por meio dos Diagramas de Classe Conceitual e de Seqüência. Desta forma, são descritos os métodos e os atributos pertencentes ao sistema. A Figura 2.6 mostra uma parte do Diagrama de Classes Geral no qual cada quadrado representa uma classe, sendo que na parte superior é colocado o nome da classe, no meio seus atributos e na parte inferior suas operações. 


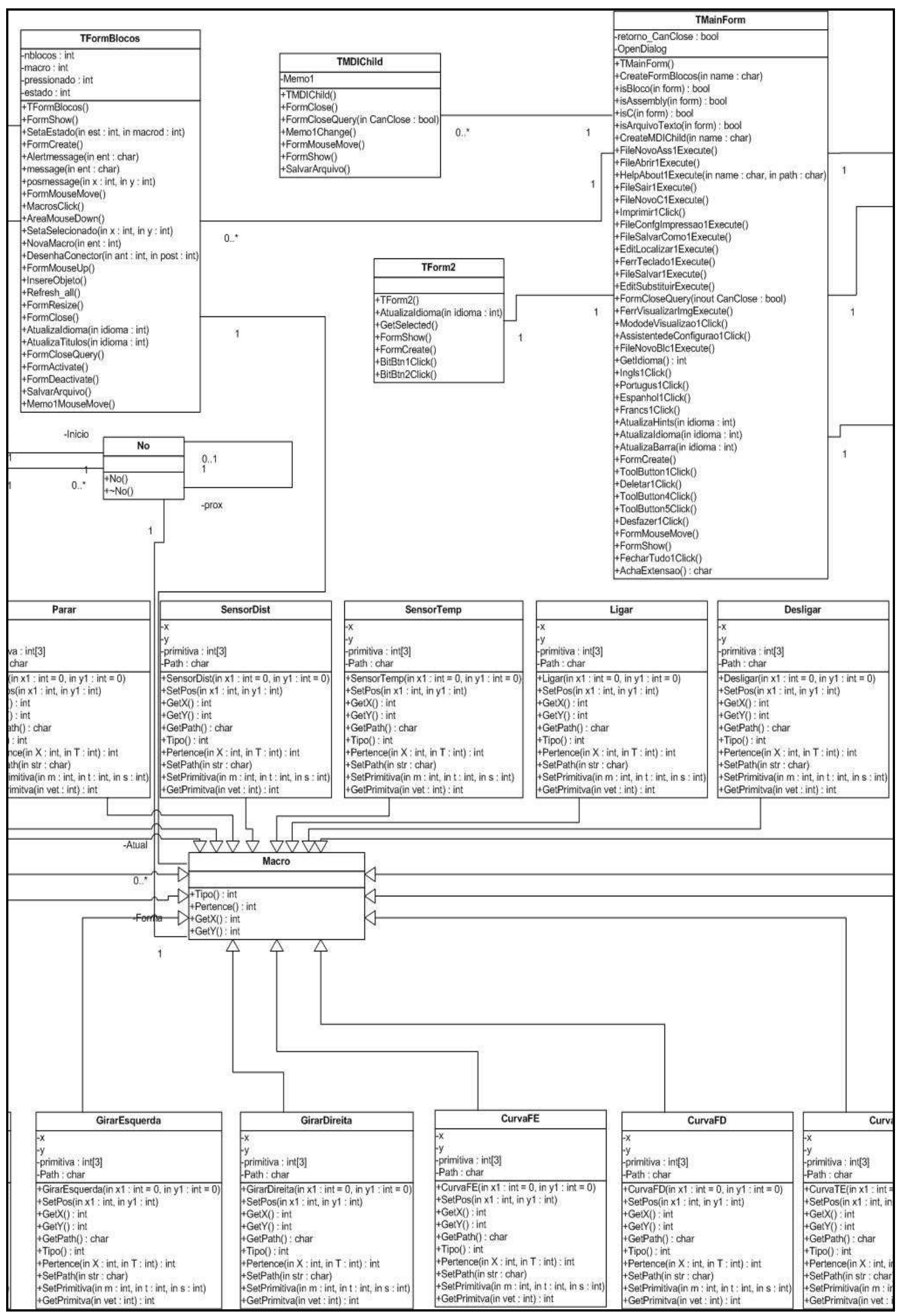

Figura 2.6 - Exemplo de Diagrama de Classes 
- Diagrama de Classes: neste documento são descritas as classes estáticas do sistema obtidas por meio dos Diagramas de Classe Conceitual e de Sequiência. Desta forma, são descritos os métodos e os atributos pertencentes ao sistema. A Figura 2.6 mostra uma parte do Diagrama de Classes Geral no qual cada quadrado representa uma classe, sendo que na parte superior é colocado o nome da classe, no meio seus atributos e na parte inferior suas operações.

Nota-se que existe uma superclasse MACRO cujas classes filhas são PARAR, SENSORDIST, GIRARESQUERDA, GIRARDIREITA, CURVAFE, CURVAFD etc. Existe também uma classe chamada TMAINFORM que é a classe que inicializa chamadas aos outros tipos de FORM, no caso TFORMBLOCOS, TFORM2 (C/Assembly).

Outra etapa importante na Engenharia de Software é a etapa de Testes que valida os atributos das classes (Figura 2.6). Foram definidas as seguintes diretrizes de cobertura para o teste de atributos:

- Verificar se os atributos especificados no diagrama de classes foram devidamente implementados:

○ Observando-se se a visibilidade dos atributos é fiel àquela definida na especificação da classe;

○ Verificando-se se o tipo do atributo declarado é igual ao especificado na classe;

- Verificar se as condições de restrição do atributo foram devidamente implementadas nos métodos que alteram esses atributos;

- Verificar se o atributo foi implementado de acordo com sua propriedade, caso essa seja declarada.

A Figura 2.7 mostra a classe AndarFrente e a Tabela 2.1 mostra os testes realizados nos seus atributos. Na classe AndarFrente o atributo $x$ possui uma restrição que é uma 
combinação com duas restrições $\{>=-32768 e<=32767\}$ incluindo o operador lógico "e".

Restrição essa oriunda da faixa de valores permitidos para variáveis do tipo int.

\begin{tabular}{|c|}
\hline AndarFrente \\
\hline $\begin{array}{l}-x \text { : int } \\
-y: \text { int } \\
\text {-primitiva : int [3] } \\
\text {-Path : char }\end{array}$ \\
\hline 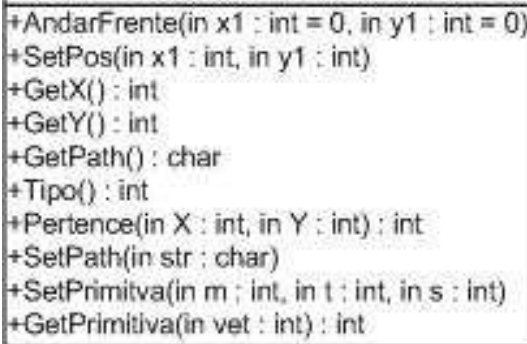 \\
\hline
\end{tabular}

Figura 2.7 - Classe AndarFrente

Tabela 2.1 - Caso de teste com os valores válidos e inválidos para o atributo $x$ em sua restrição $\{>=-$ 32768 .

\begin{tabular}{|c|c|c|c|c|}
\hline \multicolumn{3}{|c|}{ Atributo: $\mathbf{x}$} & \multicolumn{2}{|c|}{ Data Atual: 05/12/2007 } \\
\hline \multicolumn{5}{|c|}{ Restrição(ões): $\mathbf{x}>=\mathbf{- 3 2 7 6 8}$} \\
\hline & Parâmetro & Valores de Teste & Resultado Esperado & Resultado Obtido \\
\hline 1 & Valor Limite & -32768 & $\mathbf{V}$ & \\
\hline 2 & Valor Limite +1 & -32767 & $\mathbf{V}$ & \\
\hline 3 & Valor Limite - 1 & -32769 & $\mathbf{F}$ & \\
\hline
\end{tabular}




\section{Capítulo 3}

\section{Ambiente de Programação de Robôs Móveis}

O ambiente de programação proposto nessa dissertação possibilita a programação e controle dos robôs, contendo: interface gráfica, ambiente para a programação visual dos robôs, ambiente para programação em linguagem $\mathrm{C}$, ambiente para programação dos robôs em linguagem Assembly. Na interface gráfica, o usuário pode controlar e programar o robô sem a necessidade de conhecimento de linguagens computacionais avançadas. O usuário poderá controlar os movimentos do robô através do teclado ou de um joystick. Neste modo, o robô não será independente do usuário. A independência do tipo de robô é conseguida com a utilização dos três ambientes de programação e principalmente por meio da gramática criada, no qual um programa desenvolvido pelo usuário é compilado em linguagem de máquina e carregado no robô.

O ambiente de programação visual permite aos usuários leigos em programação montar um algoritmo arrastando e conectando blocos, que correspondem a macros de funções do robô, em uma seqüência que representa a ordem das ações que o robô deve executar. Essa sequiência de blocos é compilada para a linguagem de máquina compatível com o robô e, então, é enviada para a memória do mesmo por meio de um rádio-modem.

Os usuários que conhecem a linguagem $\mathrm{C}$ podem programar o robô por meio de uma janela de texto que aparecerá quando o botão correspondente a essa função for acionado. Neste caso, o programa em C será compilado para a linguagem de máquina compatível com o robô e será então enviada para a memória do mesmo por meio de um rádio-modem.

Os usuários avançados que conhecem a linguagem Assembly podem programar o robô por meio de uma janela de texto que aparecerá quando o botão correspondente a essa função for acionado. Neste caso, o programa em Assembly é compilado para a linguagem de máquina 
compatível com o robô e, então, é enviado para a memória do mesmo por meio de um rádiomodem.

\subsection{Internacionalização do Software}

Nesta Seção, são abordadas as diretrizes para a criação de aplicações que se pretende distribuir para um mercado internacional. Com um prévio planejamento, pode-se reduzir os custos em tempo e código necessários para tornar uma dada aplicação funcional tanto no mercado internacional, quanto no mercado doméstico.

Para se criar uma aplicação que se deseja implantar no mercado internacional, existem dois passos principais que devem ser realizados [36]:

- Internacionalização.

- Localização.

A edição Professional do C++ Builder 6 inclui ferramentas de tradução, que podem ser utilizadas para gerenciar localização. Localização é o processo de tradução de uma aplicação para que ela funcione em um local específico [35]. Além de traduzir a interface do usuário, a localização pode incluir tarefas personalizadas. Por exemplo, uma aplicação financeira pode ser modificada devido à lei de imposto em diferentes países.

Internacionalização é o processo de habilitar uma aplicação para que funcione em múltiplas localidades. Um local é o meio-ambiente do usuário, o qual inclui as convenções culturais do país assim como sua língua. O Windows suporta um grande conjunto de locais, cada qual descrito pelo par língua e país.

Para se criar uma aplicação internacionalizada deve-se seguir os seguintes passos:

- Permitir que o código manipule strings de conjuntos de caracteres internacionais.

- Projetar a interface do usuário para que acomode as mudanças resultantes da localização.

- Isolar todos os recursos que precisam ser localizados. 
No projeto não foram utilizadas as ferramentas de tradução do $\mathrm{C}++$ Builder, porque estas foram desenvolvidas para a biblioteca VCL o que dificulta a migração para a plataforma Linux. No entanto, a internacionalização foi aplicada com o desenvolvimento de uma biblioteca de idiomas. A biblioteca de idiomas faz a tradução de toda a interface do usuário para o idioma selecionado no menu do programa principal. Os idiomas suportados são o português do Brasil, o inglês dos EUA, o espanhol e o francês como se pode constatar na Figura 3.1.

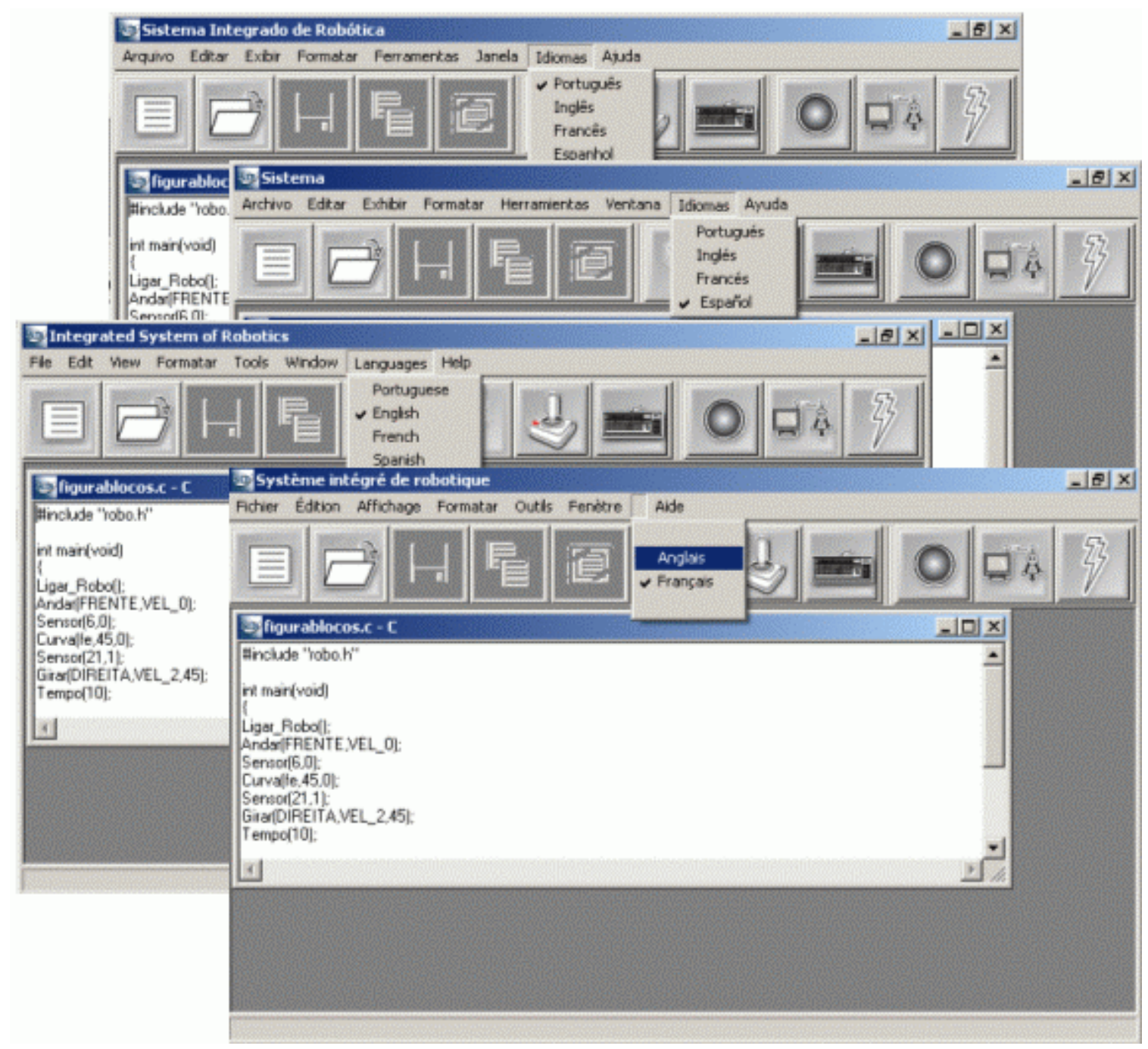

Figura 3.1 - Ambiente de programação com os idiomas suportados. 


\subsection{Projeto da Interface}

Uma das etapas principais do processo de engenharia de software é o projeto da interface [37]. Depois de analisados os requisitos do sistema e estruturado o projeto de navegação (menus e botões) do software, passou-se a estudar quais deveriam ser as características da interface do ambiente, levando-se em consideração que ele deve ser de fácil manipulação e que uma de suas muitas aplicações está voltada ao ensino. Portanto, o ambiente deve incorporar conceitos didáticos e pedagógicos.

Com essas informações, adotou-se os seguintes padrões para fonte: MS Sans tamanho 10, e para botões: dimensão 50x50 pixels, esse tamanho foi escolhido fazendo alusão aos botões de monitores touchscreen amplamente utilizados em mercados, bancos, e jogos. $\mathrm{Na}$ figura 3.2 é mostrada a primeira tela do sistema.

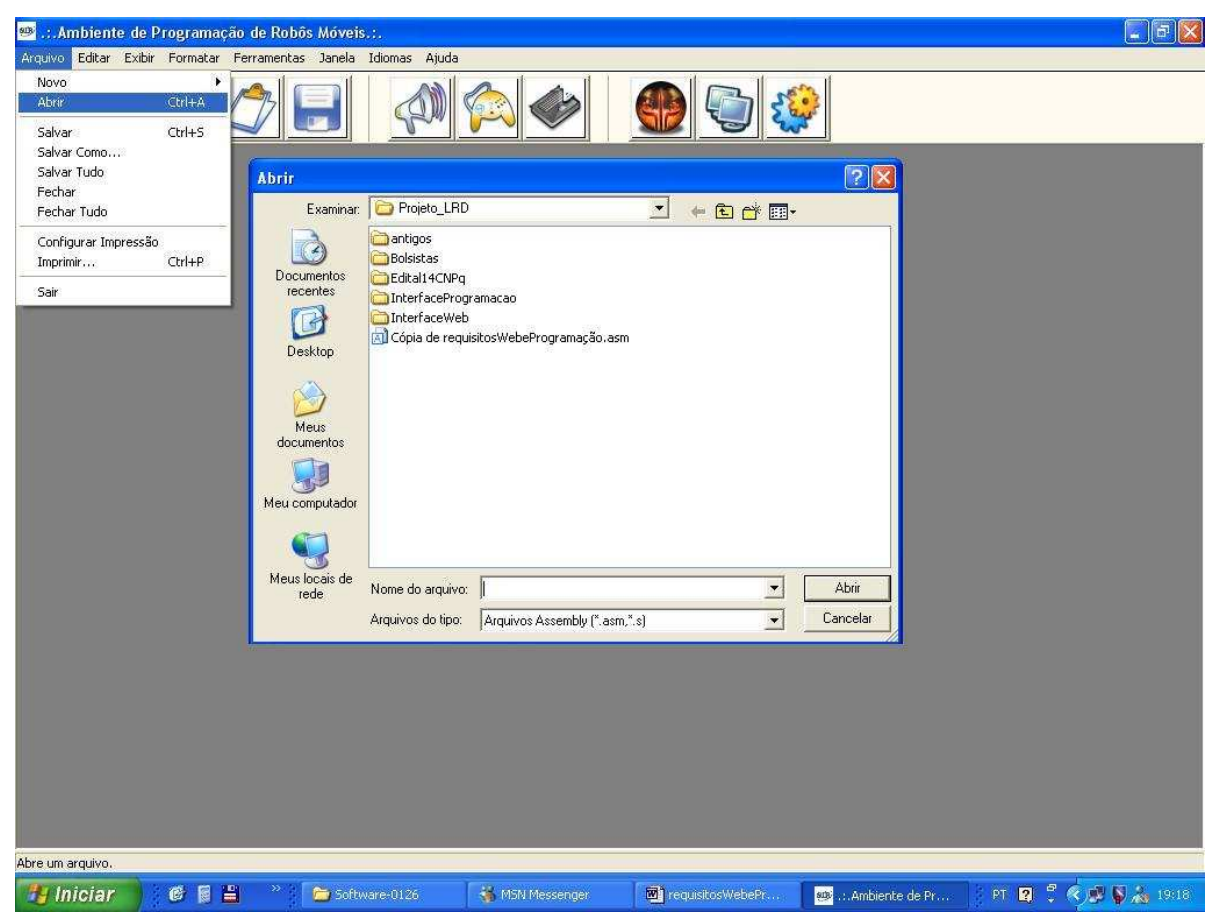

Figura 3.2 - Tela inicial do sistema integrado de robótica. 
Outra característica importante implementada no projeto de interface foi o conceito de MDI (Multiple-Document Interface Applications) [38], que permite a exibição de múltiplos documentos ao mesmo tempo, com cada documento exibido em sua própria janela. Aplicações MDI freqüentemente possuem um item de menu que permite a alternação das janelas abertas. Um exemplo do conceito de MDI pode ser visualizado na Figura 3.3.

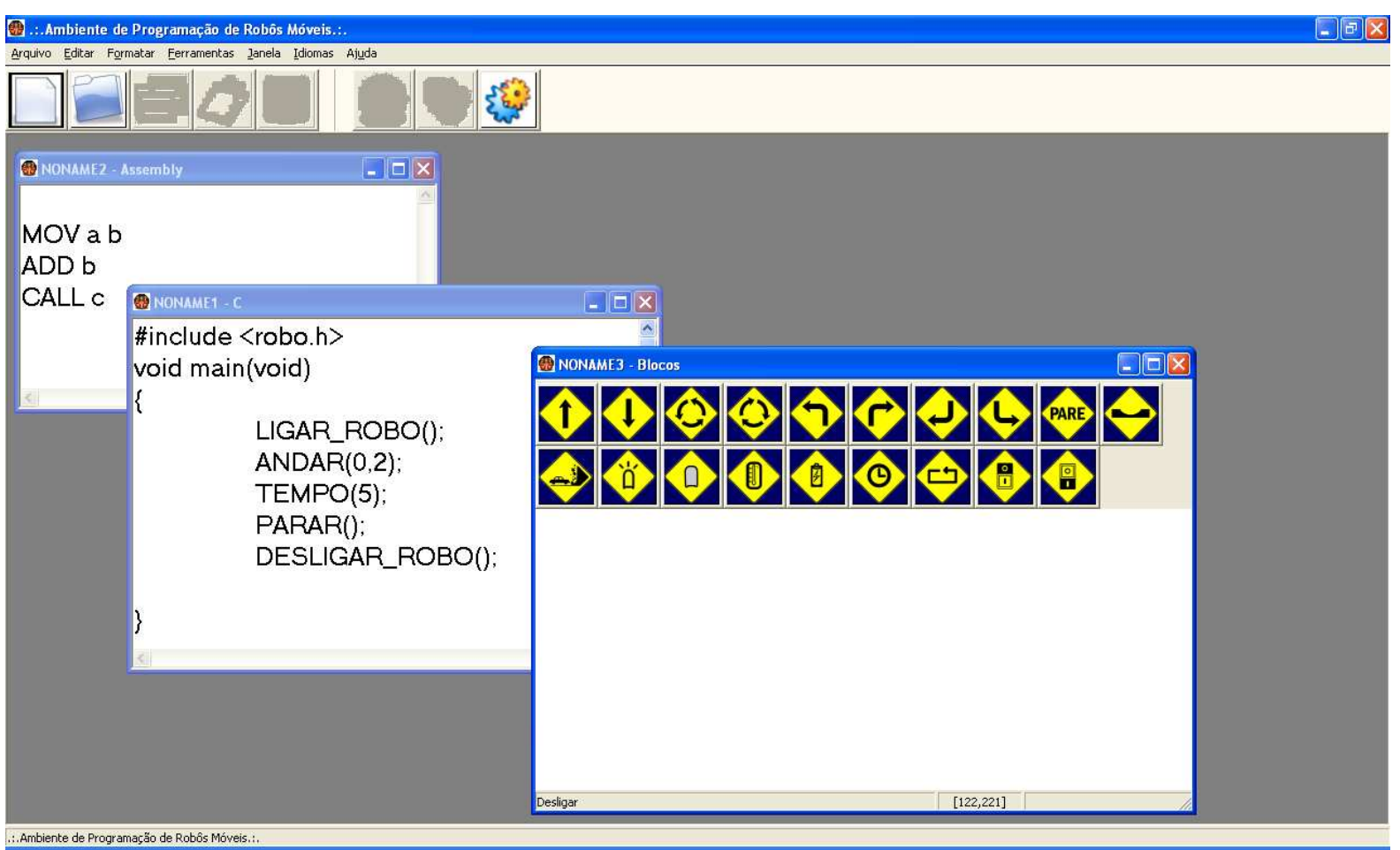

Figura 3.3 - Aplicação MDI com alternação de janelas.

\subsection{Portabilidade para Plataformas Windows e Linux}

O C++ Builder permite o desenvolvimento de aplicações de 32-bit portáveis que funcionam tanto no sistema operacional Windows quanto no Linux. Aplicações portáveis em plataforma (Cross-Plataform) usam componentes CLX (Component Library for CrossPlataform) e não fazem chamadas a APIs (Application Plataform Interface) de nenhum sistema operacional específico. 
Existem duas abordagens para o desenvolvimento de uma aplicação portável, a criação de uma nova aplicação CLX ou a modificação de uma aplicação VCL existente. Depois de executada uma das duas abordagens a aplicação está pronta para ser compilada e executada em qualquer uma das duas plataformas (Windows e Linux). Neste trabalho foi utilizada a ferramenta C++ Builder da Borland para o desenvolvimento do Sistema Integrado de Robótica usando a plataforma Windows.

A Borland não dispõe de uma solução C++ para Linux usando a plataforma Windows, contudo, atualmente é possível preparar a migração desenvolvendo a aplicação com C++ Builder. No decorrer desta Seção, serão descritos como modificar aplicações C++ Builder para que possam compilar no Linux e como escrever código independente de plataforma e portável entre os dois ambientes. Além disso, são mostradas as diferenças entre o desenvolvimento de aplicações no Windows e no Linux [21].

\subsubsection{Portando Aplicações Windows para o Linux}

Aplicações C++ Builder que foram escritas para o ambiente Windows, podem ser preparadas para o ambiente Linux. Quão fácil será esta tarefa dependerá da natureza e da complexidade da aplicação e da quantidade de dependências explícitas do Windows.

Encontra-se na literatura [22] [31] três técnicas recomendadas para transferir aplicações de uma plataforma para outra. A primeira técnica, denominada de transferência de plataforma específica, tende a consumir tempo, ter custo elevado e produzir somente um único resultado. Essa técnica cria diferentes bases de código, que se tornam difíceis de serem mantidos.

De qualquer modo, cada transferência é designada para um sistema operacional especifico e pode tirar vantagem da funcionalidade de plataforma específica. A segunda técnica, conhecida como transferência cross-plataform, consome pouco tempo porque as aplicações transferidas objetivam múltiplas plataformas. 
Todavia, a quantidade de trabalho envolvida no desenvolvimento de aplicações do tipo cross-plataform depende do código existente. Essa técnica é a abordagem preferida, porque a lógica de negócio é expressa em termos independentes de plataforma. Alguns serviços são encapsulados dentro de uma interface padrão, que parece ser a mesma em todas as plataformas, mas que possui uma implementação específica para cada uma.

Por fim, essa abordagem é a solução de menor custo, porque reduz a manutenção devido a uma base amplamente compartilhada e uma arquitetura de aplicação aprimorada.

A terceira técnica denominada emulação Windows, é a mais complexa das três e pode ser muito custosa. Entretanto, a aplicação Linux resultante assemelha-se muito mais com uma aplicação Windows. Essa abordagem envolve a implementação de funcionalidades do Windows no Linux. Do ponto de vista da Engenharia, essa solução é muito difícil de manter.

Na Tabela 3.1 abaixo estão diferentes abordagens que podem ser tomadas para portar uma aplicação de uma plataforma para outra.

Tabela 3.1 - Técnicas de transferência.

\begin{tabular}{|l|l|}
\hline Técnica & Descrição \\
\hline Plataforma-específica & Objetiva um sistema operacional e APIs base \\
\hline Plataforma-portável & Objetiva uma API portável (Cross-Plataform) \\
\hline Emulação Windows & $\begin{array}{l}\text { Não altera o código e porta a Interface da Plataforma de Aplicação } \\
\text { (API) que ele usa }\end{array}$ \\
\hline
\end{tabular}

\subsection{Migração de Software do Windows para Linux}

Migrar uma aplicação que se deseja executar tanto na plataforma Windows quanto na Linux, exige modificação do código ou a utilização de diretivas de compilação condicionais (\#ifdefs) que indiquem porções do código especificamente aplicadas para Windows ou Linux. Os passos listados a seguir, são diretivas que ensinam como migrar uma aplicação VCL para CLX usando o C++ Builder:

- Abrir o projeto contento a aplicação no C++ Builder. 
- Fazer uma copia dos arquivos .dfm mantendo o mesmo nome, trocando somente a extensão dos arquivos para .xfm (por exemplo, renomear unit1.dfm para unit1.xfm). Renomear (ou utilizar \#ifdefs) as referências do cabeçalho dos arquivos de \#pragma resource "*.dfm" para \#pragma resource “*.xfm”. (O arquivo .xfm funcionará tanto em aplicações $\mathrm{C}++$ Builder quanto em Linux).

- Trocar (ou utilizar \#ifdefs) todos os cabeçalhos dos arquivos fonte para que façam referência às unidades CLX corretas. Por exemplo, trocar as seguintes declarações \#include do cabeçalho de uma aplicação Windows:

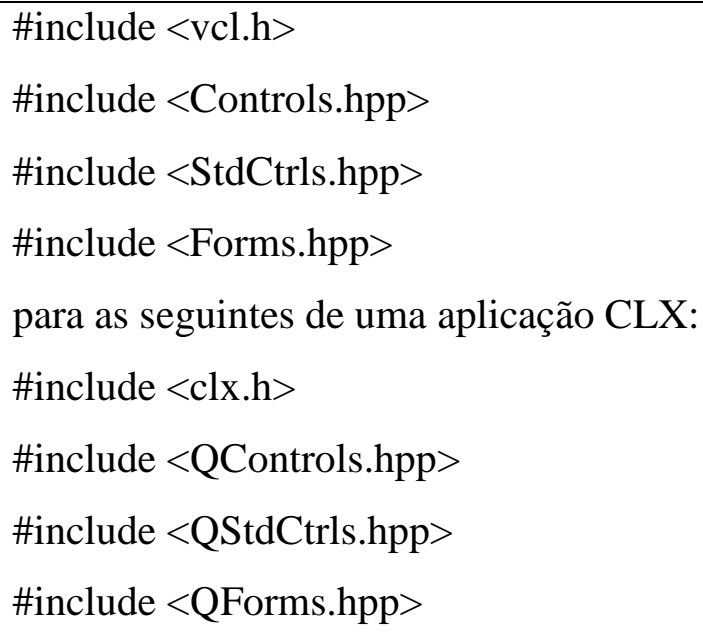

- Salvar o projeto e abri-lo novamente. A paleta de componentes do C++ Builder disponibilizará após esse passo, componentes que podem ser utilizados em aplicações CLX. Alguns componentes não visuais somente-Windows podem ser utilizados em aplicações CLX. Entretanto, estes componentes contêm funcionalidades que irão funcionar somente em aplicações CLX Windows. Caso se planeje compilar uma aplicação também na plataforma Linux, não se devem utilizar os componentes VCL não visuais, outra solução é utilizar diretivas de compilação para marcar esses trechos do código como somente Windows. 
- Reescrever todo código que requeira dependências Windows tornando-o mais independente de plataforma.

- Encontrar funcionalidades equivalentes para características que são diferentes no Linux. Utilize \#ifdefs (moderadamente) para delimitar informações especificas do Windows. Por exemplo, é possível definir código de plataforma específica nos arquivos fontes da aplicação:

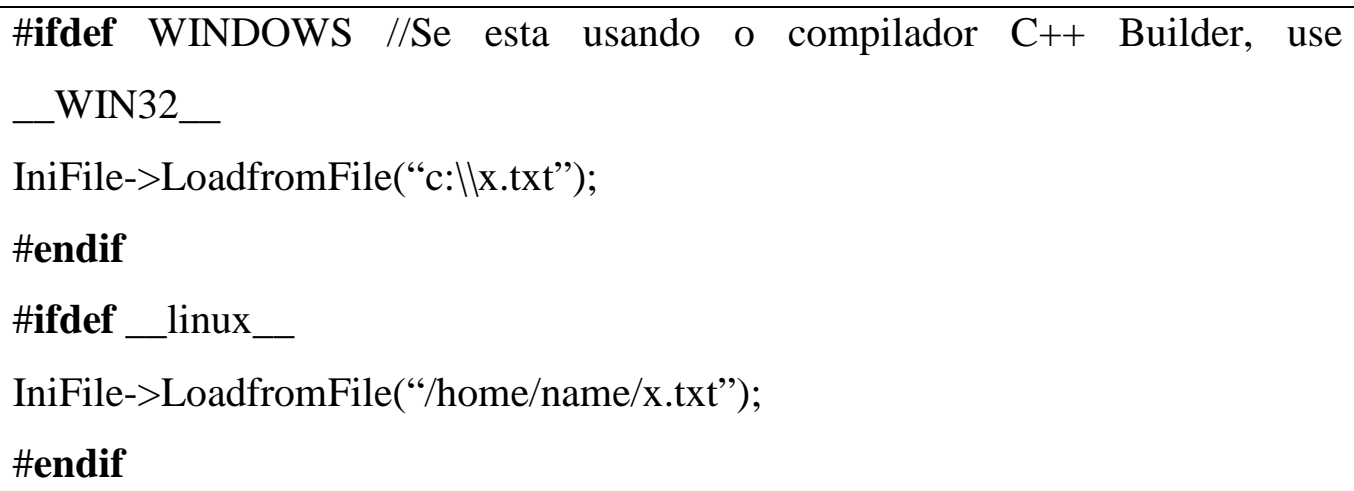

- Procurar por referências a caminhos (diretórios) em todos os arquivos do projeto:

- Nome de diretórios no Linux usa a barra (/) como delimitador (por exemplo, /usr/lib) e arquivos podem estar situados em diferentes diretórios no sistema Linux.

- Trocar as referências e códigos que procuram letras indicativas de drive (por exemplo, C:l) por dois pontos (:) na posição 2 da string.

- Em locais onde se especifica múltiplos diretórios, troque o separador de diretórios de ponto e virgula (;) por dois pontos (:).

- Devido nome de arquivos serem sensíveis a caixa no Linux, é preciso certificar-se que a aplicação não muda a caixa para nomes de arquivos ou assuma uma caixa específica.

- Compilar, testar e depurar a aplicação. 


\subsection{Linguagens Formais e Compiladores}

Entende-se por Teoria das Linguagens Formais e dos Autômatos [23] o estudo de modelos matemáticos que possibilitam a especificação e o reconhecimento de linguagens, suas classificações, estruturas, propriedades, características e inter-relacionamentos. A importância da aplicação desta teoria no projeto é dupla: ela apóia outros aspectos teóricos da Ciência da Computação (decidibilidade, computabilidade, complexidade computacional, por exemplo), e fundamenta diversas aplicações computacionais tais como processamento de linguagens, reconhecimento de padrões, modelagem de sistemas.

Para definir o que é a Teoria das Linguagens Formais, é necessário definir o que é Linguagem e o que é Linguagem formal [24]. Pode-se definir uma linguagem como sendo uma forma de comunicação. Elaborando um pouco mais esta definição, é possível definir uma linguagem como sendo um conjunto de elementos (símbolos) e um conjunto de métodos (regras) para combinar estes elementos, usado e entendido por uma determinada comunidade. São exemplos: as linguagens naturais (ou idiomas), linguagens de programação e os protocolos de comunicação.

Linguagens formais são mecanismos formais para representação/especificação de linguagens, baseados na chamada Teoria da Computação. As representações podem ser feitas por reconhecedores e geradores. Os reconhecedores são dispositivos formais que servem para verificar se uma sentença pertence ou não à determinada linguagem. Esses reconhecedores são os autômatos: autômatos finitos, autômatos de pilha e máquinas de Turing [25].

Os sistemas geradores são dispositivos formais que permitem a geração sistemática de todas as sentenças de uma linguagem. Os principais sistemas geradores disponíveis são as gramáticas, das quais se destacam as gramáticas de Chomski [26]. Então, linguagens formais podem ser representadas de maneira finita e precisa por meio de sistemas com sustentação matemática. 
Um compilador [27] é um programa que traduz um texto escrito em uma linguagem fonte, em um texto equivalente escrito em uma linguagem alvo ou destino. Em geral, quando se fala em compilador o texto fonte é um programa de computador (mas não necessariamente). Tradicionalmente, um compilador traduz de uma linguagem de alto nível para uma linguagem de máquina (ou Assembly). Esta idéia é também muito estrita, pois na classe de compiladores podem ser encontrados aqueles que traduzem código de alto nível para outra linguagem também de alto nível. Outras vezes, o compilador não gera código de máquina como resultado, mas um código considerado de nível intermediário (como é o caso do compilador Java [28][29] que gera código em Java Byte Code)

\subsection{Projeto da Linguagem de Programação do Robô}

A interface permite que o usuário programe o robô de três modos distintos: programação em blocos, programação C e programação Assembly. Para facilitar a programação, foi criada uma biblioteca de primitivas de software. As primitivas de software acessam as primitivas de hardware que tornam o hardware do robô transparente ao usuário. Para a programação do robô, foi necessário, portanto, a realização de algumas etapas que consistiram na criação de uma linguagem de programação que passará a ser daqui em diante referida como Linguagem Robô. Essa linguagem é gerada por uma gramática (Gramática Robô) e posteriormente é interpretada e traduzida.

\subsubsection{Elaboração da Gramática Robô}

A elaboração da Gramática Robô teve como ponto de partida os comandos e restrições que poderiam ser dados ao robô, tais como: andar, girar, parar, sensor, tempo entre outros. Esses comandos e restrições passaram a ser as palavras reservadas da linguagem. O passo seguinte na elaboração da gramática foi a averiguação da lógica de programação, ou seja, a seqüência de comandos e restrições possíveis e permitidas, tendo sempre em mente a intenção 
de construir uma gramática regular do tipo LL1 [23]. A Gramática Robô na sua forma normal de bakus (Bakus-Naur Form - BNF) pode ser consultada na Figura 3.4.

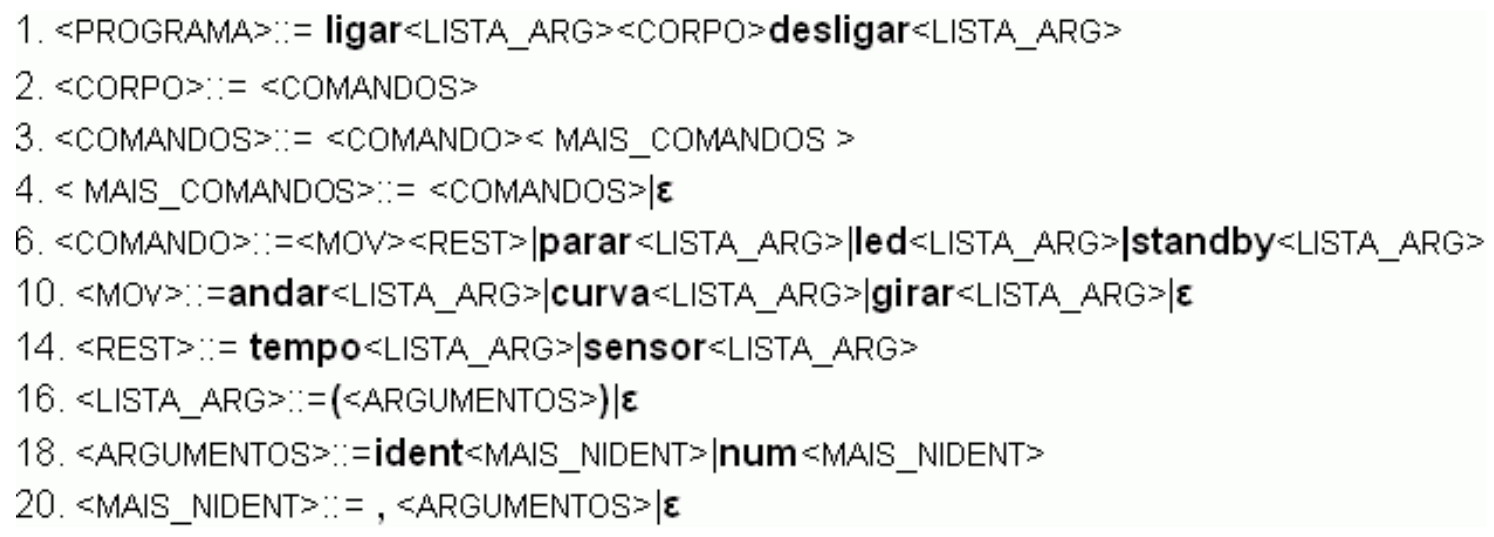

Figura 3.4 - Gramática Robô.

\subsection{Desenvolvimento do Compilador para a Gramática Robô}

Depois que o usuário fez seu programa usando a interface do Sistema Integrado de Robótica, ele precisa compilar o programa para certificar-se de que a programação está correta. Para realizar essa tarefa, é necessário um interpretador da linguagem robô, ou seja, um compilador. Um compilador é composto de várias fases; neste projeto foram implementados duas: a analise léxica que reconhece os tokens e a análise sintática que verifica se a sequiência de tokens é valida. Entretanto, um programa pode ter código robô mesclado com código C, como é o caso de um programa feito no módulo C. Por isso, as análises léxica e sintática devem levar isso em consideração. As estratégias de como foi implementada a tabela de símbolos reservados, as análises léxica e sintática para a gramática robô são descritas nas Subseções 3.8.1, 3.8.2 e 3.8.3, , respectivamente.

\subsubsection{Tabela de Símbolos Reservados}

Os símbolos reservados são cadeias de caracteres especiais de uma gramática. $\mathrm{Na}$ gramática robô, esses símbolos, que estão em negrito, são: ligar, desligar, parar, andar, curva, 
girar, led, tempo e sensor. A Tabela de Símbolos Reservados (TSR) usada pelo analisador léxico é ilustrada na Tabela 3.2:

Tabela 3.2 - Tabela de Símbolos Reservados da Gramática Robô.

\begin{tabular}{|c|c|}
\hline CADEIA (TOKEN) & CóDIGO INTERNO \\
\hline LIGAR & 0 \\
\hline ANDAR & 1 \\
\hline PARAR & 2 \\
\hline GIRAR & 3 \\
\hline CURVA & 4 \\
\hline TEMPO & 5 \\
\hline LED & 6 \\
\hline SENSOR & 7 \\
\hline STANDBY & 9 \\
\hline DESLIGAR & 10 \\
\hline
\end{tabular}

A tabela de símbolos consiste numa estrutura de dados com dois campos: a cadeia (Token), que é a palavra reservada propriamente dita, e o código interno, o valor numérico identificador.

\subsubsection{Analise Léxica}

Conforme já foi explicado, o analisador léxico da gramática robô deve considerar os casos nos quais há código mesclado, isto é, código robô e código C num mesmo programa. A estratégia implementada para compilar esse programa consiste de duas partes: uma précompilação, que faz as análises léxica e sintática do código robô, e a compilação propriamente dita, que usa o compilador MSP430-gcc.

O analisador léxico lê caracteres do programa até formar um token da linguagem robô. Quando esse token é identificado, um valor inteiro é retornado indicando qual palavra reservada foi reconhecida. Caso contrário, é retornado o valor -1 , indicando que a palavra formada não pertence à gramática. Para uma maior compreensão dos passos do analisador léxico pode-se consultar o autômato finito [30] representando os passos do analisador léxico, na Figura 3.5. 
O funcionamento do analisador léxico é como se segue: o analisador léxico "varre" o arquivo de código $\mathrm{C}$, caractere a caractere e os agrupa formando uma cadeia de caracteres. Essa cadeia é comparada com as cadeias existentes na TSR. Se houver compatibilidade, o analisador léxico deve retornar o código interno do token. Caso contrário, a cadeia formada não pertence à Gramática Robô e o analisador léxico retorna o valor inteiro -1 (menos um).

Os passos do analisador léxico, ou seja, o que ele deve fazer a cada caractere lido, estão ilustrados no autômato finito exibido na Figura 4.4. Na figura, S0, S1, ..., S9 são os possíveis estados em que o analisador léxico pode se encontrar e (a1),..., (a6) são as ações que devem ser executadas pelo analisador léxico onde:

- (a1)- inicializa cadeia com $1^{\circ}$ caractere.

- (a2)- concatena demais caracteres à cadeia.

- (a3)- compara a cadeia lida com as cadeias da TSR: se pertencer a TSR retorna código interno e avança ponteiro do arquivo até encontrar um ponto e virgula (;), senão retorna -1 e retrocede em um caractere o ponteiro de arquivo.

- (a4), (a5)- retornam -1 (menos um) e retrocedem.

- (a6)- retorna -1 (menos um). 


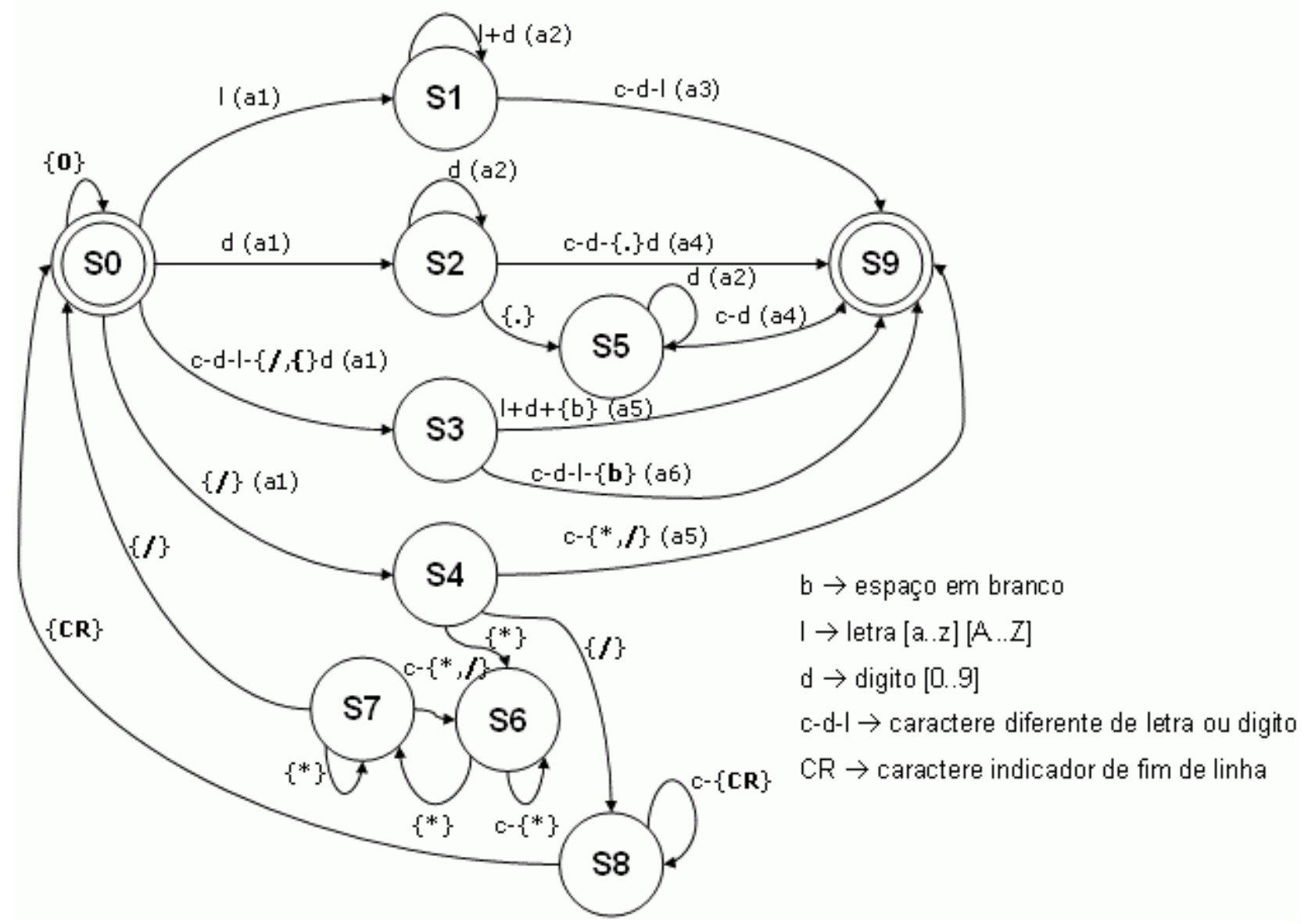

Figura 3.5 - Autômato Finito representando os passos do Analisador Léxico para a Gramática Robô.

\subsubsection{Análise Sintática}

Na análise sintática, normalmente parte-se do axioma da gramática e deve-se chegar à sentença a ser verificada, somente se esta sentença estiver correta do ponto de vista gramatical. Isto é o mesmo que construir a árvore de derivação para a sentença, a partir da raiz, e obter nas folhas os símbolos da sentença. Uma das formas de se realizar essa análise é empregando-se a Análise Descendente com Retrocesso (ADR) [25] ou o método de tentativa e erro. Este foi um dos primeiros métodos para análise sintática; apresenta grandes ineficiências quanto à utilização de memória e tempo. Ele é muito parecido com o processo utilizado para derivar árvores sintáticas.

O processo é tipicamente exploratório, pois no caso de haver várias regras com o mesmo lado esquerdo e diferentes lados direitos, ele escolhe uma e continua a análise. Caso 
tenha escolhido mal, ele seleciona outra possibilidade e continua o processo. Este termina quando o texto é reconhecido ou então se não foi possível analisá-lo após ter tentado todas as regras de produção da gramática.

Devido à ineficiência do método apresentado acima, o problema passa a ser como fazer para evitar retrocessos na análise, ou seja, conhecido o próximo símbolo da cadeia e qual o símbolo não terminal a ser derivado, determinar exatamente qual regra da Gramática deve ser aplicada. O método usado para escolher uma entre muitas regras, praticamente classifica a análise sintática. Obviamente, o método sempre exigirá certas restrições à gramática. O método recursivo descendente é uma alternativa para alcançar o objetivo descrito.

A fim de que nenhum retrocesso seja necessário, é preciso saber, dado o símbolo de entrada $a$ e o não terminal $A$ a ser expandido, qual das alternativas $A-\lambda_{1}\left|\lambda_{2}\right| \ldots \mid \lambda_{n}$ da produção é a única alternativa que deriva uma cadeia começando por a. Isto é, a alternativa adequada é detectável, olhando-se apenas o primeiro símbolo que ela deriva. Se uma alternativa de $A$ é $\lambda$, e nenhuma das outras alternativas deriva da cadeia começando com a, então pode-se expandir $A-\lambda$ aceitando a entrada $a$.

O parser recursivo descendente é um conjunto de procedimentos, um para cada não terminal a ser derivado. Para aplicar este método as gramáticas terão restrições tais como: não recursivas à esquerda $\left(A^{+}=>A \lambda\right)$, pois isso provocaria um loop infinito; e não possuir mais que um lado direito de um não terminal começando por um mesmo terminal, o que faria com que não se pudesse decidir de modo determinístico por qual optar.

A implementação de um parser recursivo descendente [25] exige o cumprimento de duas etapas: uma de transformação que consiste na passagem da gramática na forma normal de Bakus (BNF) para a representação em grafos sintáticos; e uma de tradução que traduz os 
grafos sintáticos em procedimentos. Nas Figuras 3.6 e 3.7 são mostradas as etapas de transformação e tradução da Gramática Robô respectivamente.

As gramáticas que satisfazem o requisito de apenas ser necessário um único símbolo à frente para decidir que caminho a seguir, são chamadas Gramáticas LL(1) [39]. A idéia que está por trás do analisador sintático para gramáticas LL(k) (Left to right, Leftmost derivation with $\mathrm{k}$ lookahead symbols) é que basta olhar no máximo $\mathrm{k}$ símbolos da cadeia à frente do ponto em que se está para decidir sobre qual regra aplicar. O ideal é que apenas um símbolo (k=1) seja necessário.

Algumas características, como ambigüidade e recursividade, impõem às gramáticas algumas restrições na análise sintática. Por isso, para a implementação do analisador sintático descendente (análise top-down) foi preciso eliminar as ambigüidades e recursividades à esquerda da Gramática Robô.
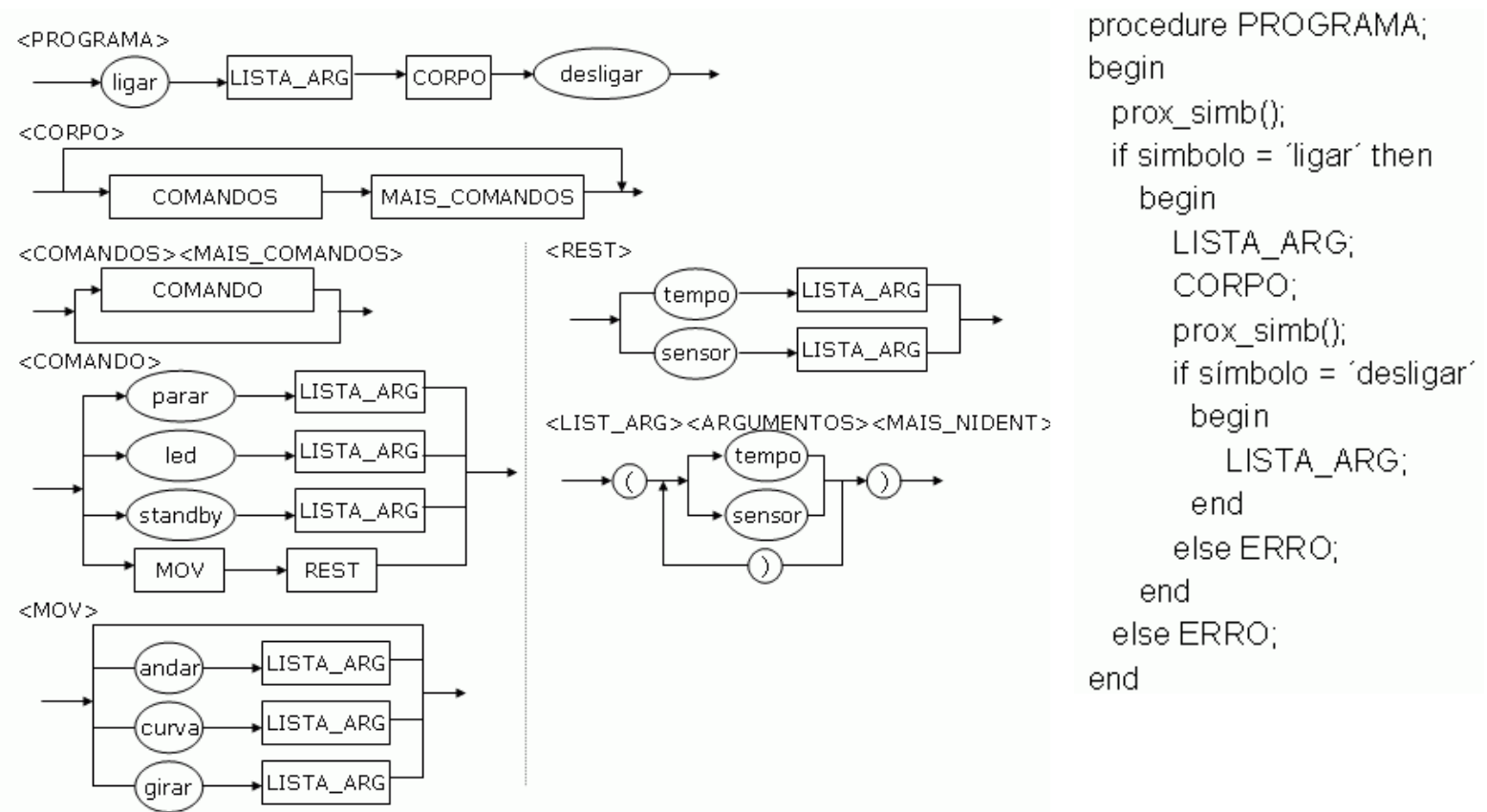

Figura 3.6 - Grafos sintáticos para a Gramática robô

Figura 3.7 - Tradução

\subsection{Desenvolvimento do Módulo Blocos}


O Sistema Integrado de Robótica possui três modulos de programação: o módulo blocos, destinado a programadores inexperientes e crianças; o módulo C voltado para programadores de níveis intermediário e avançado; e por fim o módulo assembly, desenvolvido para programadores avançados.

O principal objetivo do módulo blocos, além de fornecer uma interface intuitiva, é permitir que o usuário aprenda de forma didática a utilizar a Linguagem Robô. Essa meta é alcançada com a utilização do compilador. A medida que o usuário vai construindo seu programa no módulo blocos o compilador é acessado verificando se a seqüência de blocos está correta. Nos casos em que o usuário comete erros de programação, o compilador chama uma rotina de advertência que exibe uma caixa de mensagem indicando o erro que o usuário está cometendo e ensinando-o quais são os possiveis blocos que podem ser utilizados considerando a sequiência atual, como pode ser observado na Figura 3.8. Nessa figura, é ilustrado um programa no qual o usuário tenta comandar o robô para girar para direita estando o mesmo desligado. A mensagem de advertência informa o equívoco do usuário permitindo assim que ele modifique seu programa. 


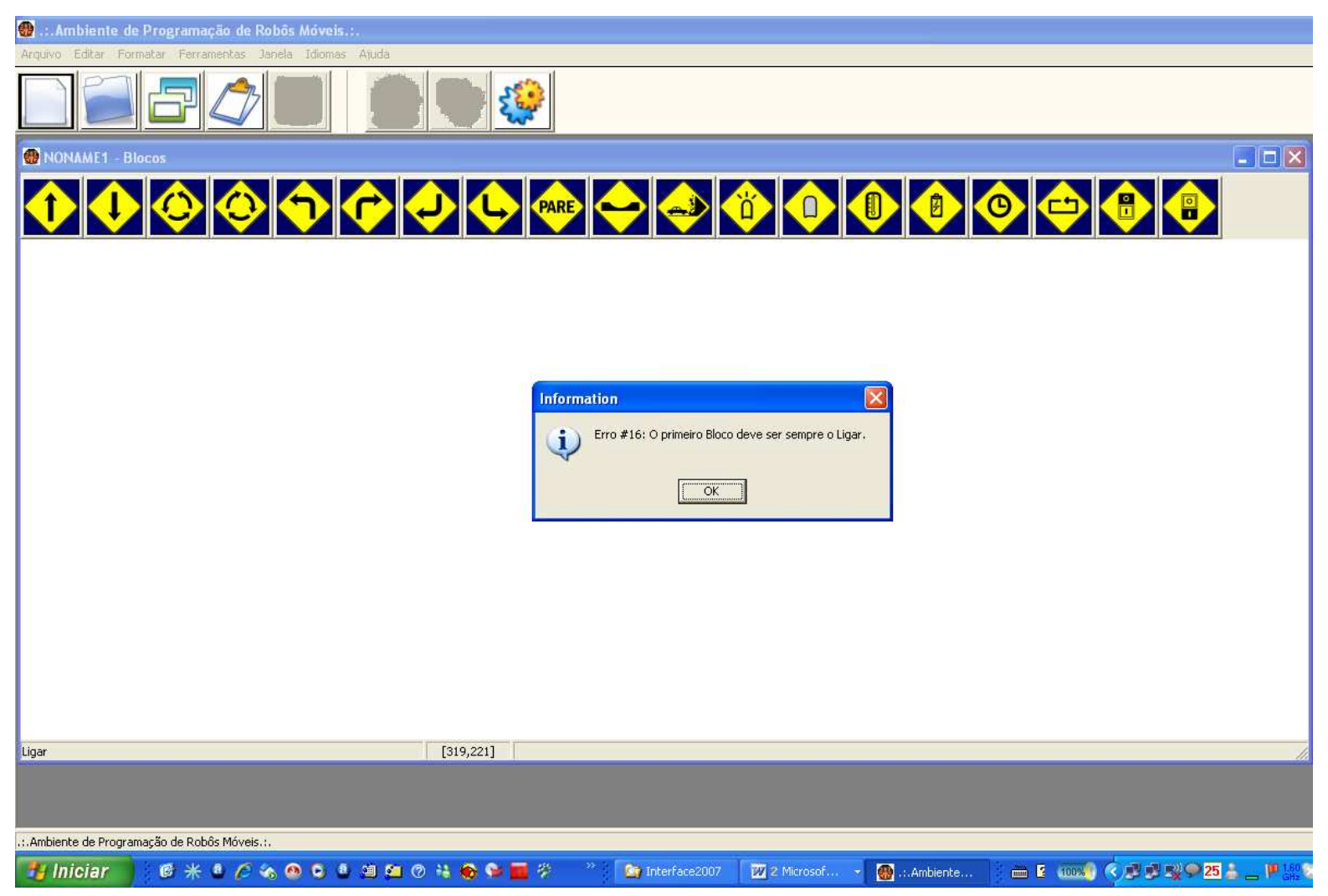

Figura 3.8 - Mensagem de advertência disparada pelo compilador.

\subsubsection{Escolha dos Ícones}

$\mathrm{Na}$ escolha dos ícones, para a representação das macros da linguagem de blocos, foram considerados dois fatores: que os ícones fossem auto-explicativos e nos casos nos quais isso não fosse possível, ou seja, casos que houveram a necessidade de inserir um texto, que esse texto fosse em inglês. Para os ícones da programação em blocos, foi seguido como modelo a simbologia de trânsito. Existem algumas vantagens de utilizar como modelo os símbolos de sinalização de trânsito que são: seu amplo emprego e conseqüentemente conhecimento por parte de crianças; sua fácil compreensão, pois, por se tratar de uma simbologia internacional, ela é compreendida por muitas nações (o que facilita a internacionalização); outra vantagem é que a simbologia de trânsito é auto-explicativa. Na tabela 3.3, são exibidos todos os 18 ícones utilizados no módulo e uma breve descrição de sua função. 
Tabela 3.3 - Tabela com a descrição dos ícones utilizados na programação blocos.

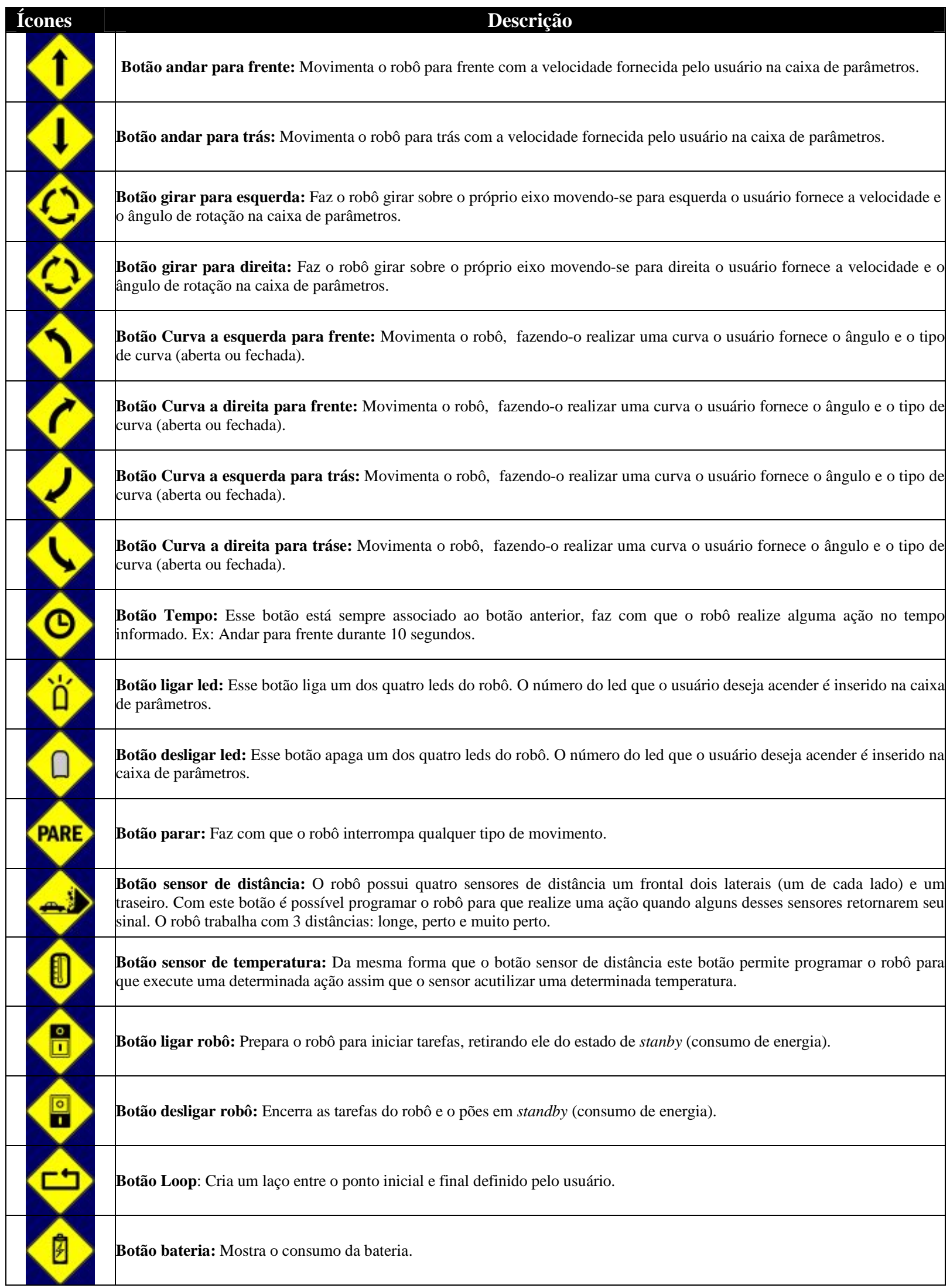




\subsubsection{Implementação das Técnicas para manipulação de blocos}

O ambiente de programação em blocos disponibiliza a manipulação dos botões, habilitando o usuário a inserir, arrastar e excluir blocos. A inserção de blocos no ambiente é realizada com a seleção do bloco, isto é, um clique no botão contendo a ação que o usuário deseja que o robô execute e um clique na área de trabalho para que um ícone representando a ação seja impresso na área de programação. Há casos nos quais a inserção de blocos é bloqueada (inserir blocos após o bloco desligar robô). Esses casos correspondem às restrições que a gramática impõe para a programação do robô. Todavia observou-se que há situações em que mesmo depois de finalizado o programa, deseja-se inserir outro bloco no meio da sequiência. A técnica implementada para realizar essa tarefa envolve o emprego dos conectores (linhas que ligam dois blocos consecutivos da seqüência de programação). Para inserir um bloco entre blocos já existentes, basta selecionar o novo bloco e clicar sobre o conector que liga os outros dois. Se a seqüência for válida, ou seja, não houver um erro sintático, o botão é inserido. Caso contrário uma mensagem é exibida ao usuário.

Para arrastar um bloco da área de trabalho o usuário deve clicar sobre o bloco e, estando este ainda pressionado, arrastá-lo até uma nova posição da tela. Para que o usuário note que o bloco pressionado está selecionado e, portanto, habilitado para movimentar-se sobre a área de trabalho, seu ícone é sombreado como pode ser constatado na Figura 3.9.

A exclusão de blocos é uma função mais complexa que as duas anteriores. Por isso, seu emprego deve ser controlado. O evento de exclusão é acionado com o clique do botão direito do mouse sobre o bloco. Quando um bloco é excluído uma mensagem pedindo confirmação da ação é exibida na tela. Além disso, é perguntado ao usuário se ele deseja que o software ligue os blocos que ficaram sem conexão ou se ele irá inserir um novo bloco no lugar do excluído. Se o usuário escolher a primeira opção (ligar os blocos sem conectores), o compilador confere se a seqüência está sintaticamente correta e valida a ação. Caso contrário, 
uma mensagem é exibida na tela informando o usuário que a conexão dos blocos não pôde ser efetuada e pergunta se ele deseja inserir um novo bloco no lugar do excluído. Caso afirmativo, o novo bloco é inserido. Senão, a exclusão é desfeita e uma mensagem é exibida na tela, informando que a exclusão não pôde ser realizada. Caso o usuário selecione a segunda opção (inserir um novo bloco no lugar do excluído), o compilador aguardará a inserção de blocos que tornem a seqüência sintaticamente correta e só a validará quando o bloco válido for inserido. Esse controle é feito para evitar erros sintáticos durante a exclusão.
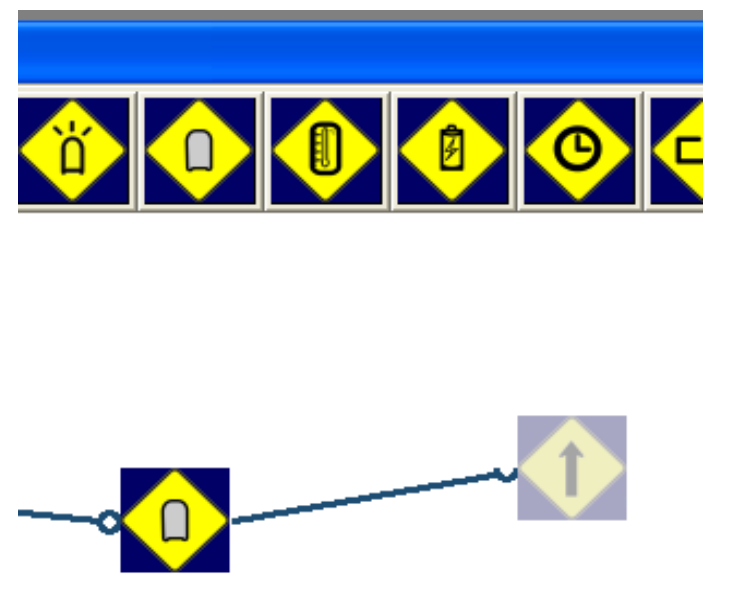

Figura 3.9 - Bloco sendo arrastado.

\subsubsection{Implementações das Técnicas para Salvar e Abrir Blocos}

Foi projetada uma biblioteca particular para o módulo blocos, contendo a definição de uma classe abstrata Macro, com classes herdeiras representando cada um dos botões de programação em blocos e uma Lista de Macros com métodos específicos de inclusão, exclusão e busca. As classes herdeiras da classe Macro possuem métodos para configurar e retornar parâmetros gerais da classe, tais como posição cartesiana na tela e tipo da classe 
(número indicando a macro selecionada), e para parâmetros específicos como velocidade, ângulo, tempo, temperatura entre outros.

Durante a programação, os blocos inseridos têm suas correspondentes classes instanciadas e incluídas na lista de blocos com todos os seus parâmetros. Quando o programa é salvo, a estrutura lista é armazenada no arquivo de extensão .blc. Ao Abrir o arquivo, a estrutura Lista é lida e a janela blocos é reconstruída.

\subsubsection{Aperfeiçoamento da Gramática do Robô}

No decorrer dos experimentos descritos na seção 4 foram detectados alguns requisitos funcionais que a gramática não atendia, como o desenvolvimento de uma nova macro para o módulo blocos que se integrasse automaticamente ao processo de compilação, assim como uma programação independente de hardware de execução, ou seja, capaz de gerar um programa independente do microprocessador utilizado nos robôs. Um exemplo prático foi detectado em um dos laboratórios realizados no Colégio São Luis Anglo Jaboticabal, onde o professor de física Sérgio Motta conduzia um desafio em que seus alunos da $5^{\text {a }}$ série do ensino fundamental deveriam programar um robô para sair de um labirinto, usando a interface de programação. Um dos alunos abordou o professor indagando se não seria possível por na interface um comando que eles usariam muito que seria o movimento de ziguezague. Isso alarmou para a necessidade de criação de macros personalizadas, ou seja, constatou-se a necessidade do ambiente permitir que o usuário criasse seus próprios blocos (macros). Foi então realizada uma refaturação da gramática robô para atender a essas necessidades, modificando o conceito formal de gramática para um conceito mais informal, que acoplasse a definição clássica da literatura mais a necessidade específica que foi detectada. Para programar tal conceito, a gramática teve sua implementação adaptada para analisar o programa, classificando as macros do módulo blocos em três categorias distintas: Movimento, Restrição e Sensor. Com isso, quando uma nova entidade bloco é criada ela é categorizada em 
uma das três classes possíveis e, na fase de análise sintática, o programa identifica a que categoria pertence o comando que está traduzindo e segue o fluxo formal de compilação.

No exemplo do ziguezague a nova macro é categorizada como uma macro de movimento e na tradução realizada pela compilação em uma primeira instância não é acusado erro sintático porque o comando de categoria "Movimento" é um comando válido. Após essa primeira verificação é analisado se este movimento é composto por um movimento personalizado, isto é, quando é criada uma nova macro são inseridos em uma tabela de macros o nome da macro, sua categoria, a quantidade de parâmetros e seus tipos. Assim, é verificado se existe na tabela macros a macro ziguezague, e neste caso o comando é reconhecido e a compilação executa seu fluxo normal de processamento. Caso contrário, a análise verifica se o token ziguezague é um terminal válido dentro do subcomando movimentos (andar, curva,girar). Se não for, um erro sintático é disparado. Essa estratégia ampliou bastante a usabilidade do ambiente de programação porque permitiu uma expansão de sua aplicação a robôs com dispositivos distintos bastando para isso configurar e criar as macros que controlam os dispositivos específicos que não vêm na versão padrão do ambiente de programação. Assim, por exemplo, um robô com garra pode ser programado bastando para isso sua adição e a correta configuração dos seus parâmetros na interface de programação. Uma desvantagem com a adoção dessa solução é a perda de desempenho, uma vez que é adicionado mais uma verificação no fluxo de compilação que é a verificação de categoria. Essa perda de desempenho não é perceptiva ao usuário, mas é significativa onde o processo de compilação passou de $20 \mathrm{~ms}$ para $33 \mathrm{~ms}$ em média, em um computador com $1 \mathrm{~Gb}$ de memória e processador de $2 \mathrm{GHz}$, representando uma perda de desempenho da ordem de $17 \%$.

Como para essa configuração foi necessário criar uma interface visual de portas específicas do microprocessador para permitir a consistência entre os dispositivos adicionados 
no modulo blocos com a arquitetura de construção do robô, outra melhoria implementada foi uma biblioteca extensível de microprocessadores. Com essa biblioteca pode-se submeter um mesmo programa para robôs com microprocessadores diferentes desde que estes sejam programáveis via código $\mathrm{C}$. Nesse trabalho foi criado bibliotecas para toda a família de microprocessadores MSP430xx da Texas Instruments [43]. O desenvolvimento de uma biblioteca de microprocessadores é também realizada por meio de uma interface visual, na qual o usuário fornece um arquivo de imagem com a arquitetura de portas do microprocessador numeradas. A interface em seguida vai conduzindo o usuário a indicar quais são as portas de alimentação (VCC) e terra (GND), em seguida é solicitado a identificação das portas de comunicação RS/TX, a porta onde estão conectados os motores do robô e assim por diante, sendo que para cada um dos dispositivos do ambiente são solicitadas as portas pelas quais são acessados. Terminado esse procedimento, o ambiente de programação está configurado para poder programar o novo processador. Na fase compilação, uma interface adicional é fornecida ao usuário solicitando a identificação do microprocessador do robô, e assim o sistema é capaz de compilar o programa para o microprocessador especificado.

\subsection{Desenvolvimento dos Módulos C e Assembly}

Os módulos C e Assembly são módulos destinados a usuários com conhecimentos de programação médio e avançado respectivamente. No presente estado de desenvolvimento, estes dois módulos são simplesmente editores de texto, contudo alguns aprimoramentos como o destaque de palavras reservadas das linguagens C, Robô e Assembly; e corretor sintático que auxilia o programador durante a digitação foram extensivamente estudados e serão abordadas com maiores detalhes nas considerações finais. 


\section{Capítulo 4}

\section{Experimentos}

Este capítulo apresenta os experimentos realizados utilizando o Ambiente de Programação de Robôs Móveis. Estes experimentos foram realizados em Escolas Públicas e em um Laboratório de Robótica à Distância. Nas Escolas Públicas o objetivo é avaliar o ambiente de programação como ferramenta de apoio ao aprendizado de Física e Raciocínio Lógico e levantamento de dados que contribuíssem para a adequação do ambiente às necessidades desse perfil de usuário. No Laboratório de Robótica a Distância a interface de programação foi testada em um ambiente web para avaliar a integração do ambiente de programação com a interface web do laboratório.

\subsection{Experimento 1: Escolas Públicas}

O ambiente de programação foi utilizado em duas escolas da rede pública do ensino médio de $5^{\mathrm{a}}$ e $8^{\mathrm{a}}$ séries nas cidades de Jaboticabal e São Carlos (escola educativa), no Estado de São Paulo, respectivamente e em eventos culturais como a Feira do Livro de Ribeirão Preto de 2006, onde o ambiente foi utilizado por cerca de 650 crianças por dia durante 10 dias seguidos. O intuito desse experimento foi avaliar o ambiente de programação como ferramenta de apoio ao aprendizado de Física e Raciocínio Lógico e levantar dados que pudessem contribuir para a adequação do ambiente às necessidades desse perfil de usuário. Por meio do ambiente de programação os professores elaboravam problemas em que os alunos deveriam utilizar a ferramenta para solucionar essa tarefa e depois submeter suas soluções ao robô e comparar o resultado obtido com o esperado. 
Os professores puderam então aproveitar os experimentos para explicar fenômenos como atrito, inércia, resistência, cinemática e lógica matemática.

Experiências no sentido de aproximar o ambiente de um software educacional prazeroso, desafiador, interativo e flexível vêm sendo realizadas pelos alunos do Laboratório de Robótica Móvel do ICMC-USP. Um dos objetivos na utilização de ambientes educacionais é a busca pela motivação e pela construção do conhecimento pela própria criança. Neste contexto, a robótica oferece uma plataforma multidisciplinar com grande poder de motivação que pode ser utilizada para alunos e professores de diversas áreas do conhecimento em torno de um objetivo comum, que pode ser um jogo onde robôs de vários alunos tenham que interagir e cooperar para realizar um desafio proposto pelo professor [44].

É interessante ressaltar que o ambiente educacional desenvolvido pode ser utilizado nas escolas para ensino de diversas matérias. Nos itens seguintes serão mostrados os levantamentos realizados e os resultados obtidos com o emprego do ambiente de programação em escolas públicas.

\subsubsection{Kit Escolas Públicas}

Foi construído um robô móvel autônomo de médio porte, constituído de uma base com motores, sensores e baterias controlada por um microprocessador MSP 430 da Texas Instruments. Sobre esta base, são encaixados módulos funcionais distintos, contendo leds, câmera de vídeo, nos quais serão executados algoritmos de controle de comportamento inteligente, reconhecimento de imagem. A Figura 4.1 apresenta esse robô. As funcionalidades do robô poderão ser modificadas pelo professor ou de maneira autônoma, possibilitando que o robô aprenda ao ser treinado pelos alunos. 


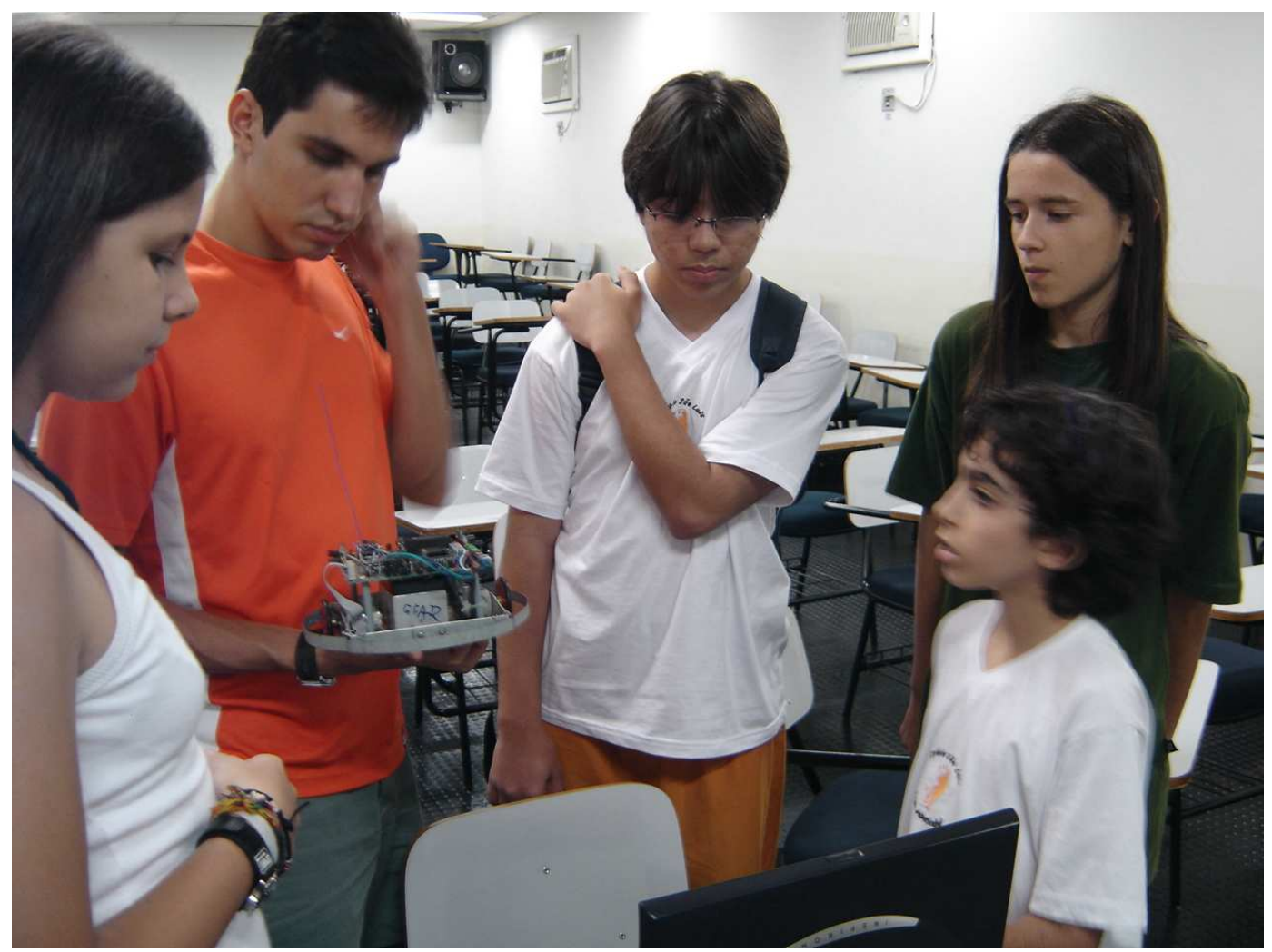

Figura 4.1 - Robô móvel autônomo de médio porte.

Em 28 de agosto de 2005 ocorreu em Bauru, São Paulo, a "Feira de Profissões Campus Interior" da Universidade de São Paulo. Neste evento acompanhando o Instituto de Ciências Matemáticas e de Computação (ICMC) entrevistou-se alguns visitantes que passaram pelo estande. No estande do ICMC estava exposto um protótipo do robô que se pretende utilizar em salas de aulas. O robô em questão tinha a capacidade de desviar de paredes e de quaisquer objetos que se interpusesse em seu caminho, sem programação prévia dos obstáculos. Todos os entrevistados observaram o robô e ouviram uma explicação sobre seu funcionamento ministrada pelo aluno de mestrado que estava desenvolvendo o robô. A participação e o interesse dos jovens presentes foi bastante significativa. As Figuras 4.2 e 4.3 mostram a quantidade de entrevistados (44) e o grau de escolaridade deles. 


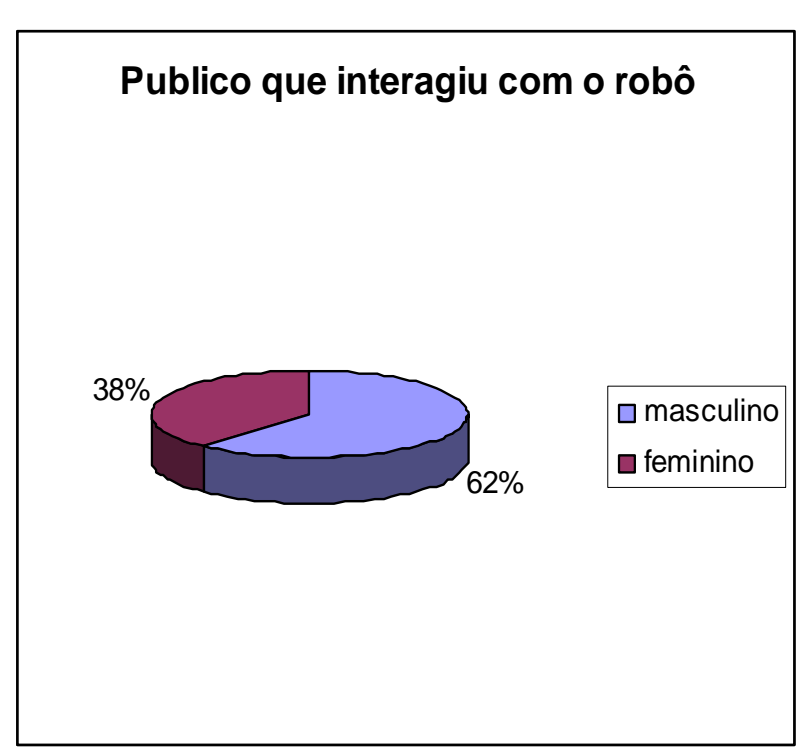

Figura 4.2 - Gráfico da Quantidade de Entrevistados

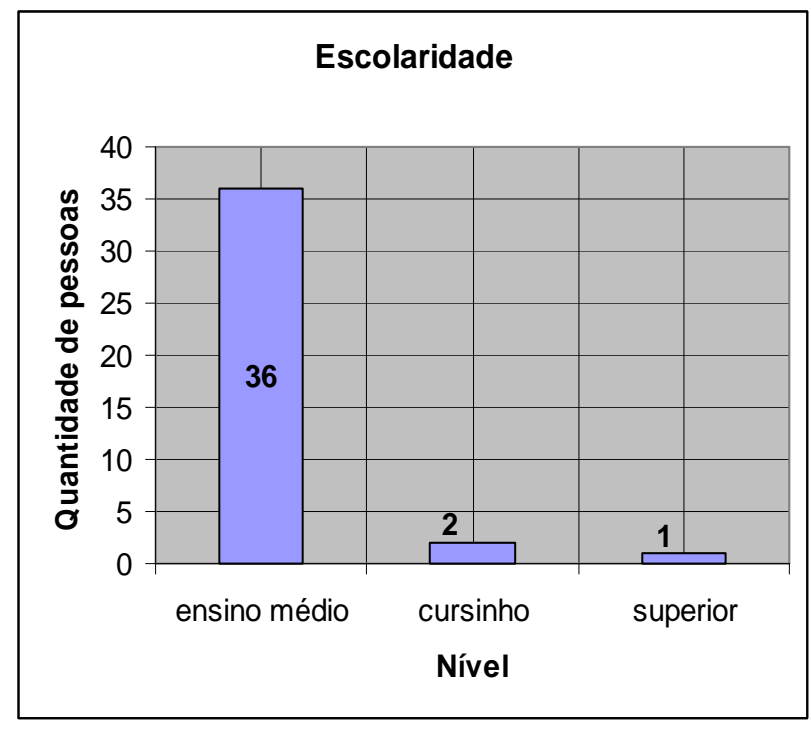

Figura 4.3 - Gráfico da Escolaridade dos Entrevistados

$\mathrm{Na}$ entrevista foram levantadas informações como a opinião do usuário na utilização de robôs como ferramentas pedagógicas, o seu maior interesse em robótica, o que mais agradou no kit robótico apresentado, qual a impressão do usuário quanto à aparência e que sugestões de melhorias eles julgavam importantes. Esses dados são mostrados na Tabela 4.1 e Figura 4.4.

Tabela 4.1 - Opinião sobre ter robôs como ferramenta pedagógica

\begin{tabular}{|l|l|}
\hline \multicolumn{1}{|c|}{ Apóia } & \multicolumn{1}{|c|}{ Não Apóia } \\
\hline $35(79,55 \%)$ não justificaram & $5(11,36 \%)$ justificaram \\
\hline $4(9,09 \%)$ justificaram a opinião & \\
\hline
\end{tabular}

Dos 44 entrevistados, 9 justificaram sua opinião, sendo 4 justificativas apoiando a utilização do robô como ferramenta pedagógica e 5 justificativas não apoiando. Das opiniões que justificavam o apoio houve 1 que mencionou ajuda à deficientes e as outras 3 que mencionaram o incentivo pedagógico. Dos que não apóiam e justificaram a opinião 3 não apóiam por achar que não é seguro e 2 acreditam que isso poderá refletir em aumento da contribuição mensal de pais e mestres. 


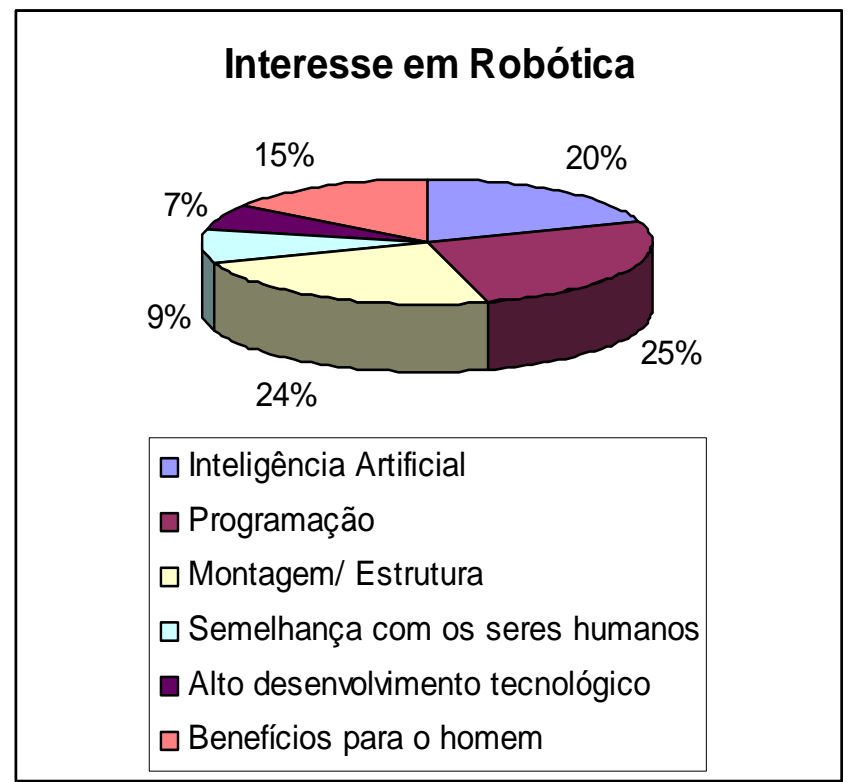

Figura 4.4 - Gráfico com dados referente ao interesse do usuário em Robótica

Alguns entrevistados demonstraram interesse em mais de uma área da robótica e podese notar que dentro desse espaço amostral de entrevistados $50 \%$ se interessam pela programação ou montagem de robôs (Tabela 4.2). Esses dados foram importantes para a realização de um estudo de usabilidade na interface de programação e de flexibilização da gramática de interpretação de comandos com o intuito de tornar ainda mais amigável a programação de robôs por meio da interface.

Tabela 4.2 - Dados apresentados o que o usuário mais gostou nos robôs

\begin{tabular}{|l|l|l|}
\hline \multicolumn{1}{|c|}{ Características dos robôs apresentados } & \multicolumn{1}{c|}{ Número de pessoas } \\
\hline Autonomia & 6 & $11,76 \%$ \\
\hline Montagem & 5 & $9,8 \%$ \\
\hline Programação & 9 & $17,65 \%$ \\
\hline Semelhança humana & 6 & $11,76 \%$ \\
\hline Sensores / Percepção & 20 & $39,23 \%$ \\
\hline Inteligência de quem desenvolveu & 4 & $7,84 \%$ \\
\hline Tudo & 1 & $1,96 \%$ \\
\hline
\end{tabular}

Houve um total de 51 votos, o que indica que mais de um item despertou interesse nos entrevistados. A percepção por meio de sensores ou a programação representou $56,85 \%$ do interesse do público entrevistado. Esse levantamento chamou a atenção para outro quesito: o 
usuário, além de apresentar interesse em se poder controlar um robô, também tem interesse em poder programá-lo e vê-lo executar sua programação de modo autônomo.

Na entrevista, o público foi questionado também quanto a sugestões de como melhorar os robôs. Houve 28 votos para a estética e 21 votos para itens não estéticos, entre s quais foram citados os seguintes itens: aplicações de entretenimento ${ }^{1}$ (13 votos), material informativo $^{2}$ (4 votos) e mais funcionalidades (4 votos). Na categoria "material informativo" estão englobadas sugestões tais como: desenvolvimento de material informativo sobre os robôs, a aparência ser personalizável, disponibilizar às escolas, fazer palestras/apresentações sobre o assunto e disponibilizar as ferramentas para os usuários programar os robôs.

Dessa experiência é possível perceber que a robótica possui muitos interessados no Brasil e que os potenciais usuários estão aguardando a melhoria das condições de utilização. O emprego da robótica em ambientes educacionais pode ser uma ferramenta adequada para o desenvolvimento de atividades que envolvam criar, projetar e planejar favorecendo assim um processo inovador de ensino-aprendizagem. Nesse sentido, a ferramenta de programação proposta nesse trabalho pode ser adaptada como ferramenta pedagógica e pode servir como uma ferramenta de auxílio ao professor.

\subsection{Experimento 2: Laboratório de Robótica a Distância}

Um Laboratório de Robótica a Distância (LRD) é um laboratório que disponibiliza recursos para uma ou mais pessoas que estejam em locais distantes interagirem em um espaço remoto, com o poder de monitorar e atuar em tal espaço, programando e controlando dispositivos robóticos ou participando de jogos educacionais. Normalmente são utilizadas técnicas de teleprogramação [60], teleoperação e telemonitoração via Internet [32].

\footnotetext{
1 Na categoria "entretenimento" estão englobados sugestões como tais: animação para tirar crianças da TV, o robô ser um brinquedo, dançar.

$2 \mathrm{Na}$ categoria "material informativo" estão englobadas sugestões tais como: criação de material informativo sobre os robôs, a aparência ser personalizável, levar às escolas, fazer palestras/ apresentações, o usuário poder programar o robô.
} 
O LRD utilizado neste experimento é o Laboratório de Robótica Móvel do Instituto de Ciências Matemáticas e de Computação da Universidade de São Paulo (ICMC - USP) que está em fase de implantação. Estará à disposição de alunos de escolas ou de universidades públicas brasileiras mediante o cadastramento e agendamento via e-mail. Após o cadastro o grupo de alunos poderá planejar um experimento com robôs, escrever o programa em linguagem $\mathrm{C}$ ou através dos Blocos do software de programação e fazer o upload dos programas via Interface Web para que o programa possa ser embarcado no robô via conexão sem fio (wireless) ou via cabo (jtag) para cada um dos robôs via Internet.

Esse experimento consiste em se testar a interface de programação num ambiente web. A idéia foi disponibilizar o ambiente de programação no site do LRD para que o usuário possa fazer o download executar localmente seus experimentos e depois submeter os programas por meio da interface do LRD. Como o projeto LRD ocorreu paralelamente ao desenvolvimento do projeto proposto nesse trabalho não houve problemas no projeto de integração entre o LRD e o ambiente de programação. O LRD recebe um arquivo gerado em $\mathrm{C}$ para o servidor de aplicação e realiza a compilação, o tratamento de exceção e depois submete para o robô. No ambiente de programação, quando não é selecionada a opção para envio de programa via JTAG ou rádio-modem, o software entende por padrão que o programa será submetido para o LRD e então ele não executa a compilação localmente, fazendo apenas uma tradução do código com macros para código C de baixo nível e submete para o servidor de aplicação do LRD. O servidor do LRD então compila o programa e programa o robô do laboratório via rádio-modem.

Na execução em ambiente de teste não ocorreram problemas. Como o LRD ainda não teve uma carga de usuários alta para avaliar eventuais problemas de acesso ou protocolo de envio de programas para o servidor, não há dados suficientes até o presente momento da escrita dessa monografia para afirmar que o emprego do ambiente de programação está 
totalmente adequado à escalabilidade do LRD. Contudo, diante da solução adotada espera-se que se confirmem as expectativas de que os dois projetos sejam de fato totalmente integrados. 


\section{Capítulo 5}

\section{Conclusões}

O trabalho proposto apresenta um ambiente de programação para robôs móveis autônomos com uma gramática flexível independente de arquitetura. Foram apresentados no Capítulo 2 outros ambientes de programação que apresentam inúmeras características e opções para programação de robôs móveis. Apresentou-se também o processo de desenvolvimento do ambiente de programação e como funciona a gramática proposta nesse trabalho.

A contribuição mais importante desse trabalho se encontra na solução adotada para a gramática de robôs, que diferentemente das abordagens tradicionais permite a criação em tempo de execução de novos elementos (macros), o que fornece uma flexibilidade de desenvolvimento de novos programas. $\mathrm{O}$ ambiente de programação também apresenta um módulo para inclusão de novas plataformas (microprocessadores) de programação. Até o presente momento, o ambiente já contém em sua biblioteca todos os microprocessadores da família MSP430 O ambiente possui um módulo que auxilia o usuário a configurar as macros (blocos de programação) e dispositivos do robô para os diferentes microprocessadores contidos em sua biblioteca, como, por exemplo, a porta em que está o motor ou em que porta do microprocessador ficará um led, fornecendo ao ambiente independência de construção de plataforma do robô Assim, robôs com arquiteturas diferentes podem ser igualmente programados por meio desse ambiente.

A gramática para atender esses requisitos sofreu uma pequena modificação, passando por uma análise sintática diferenciada que divide o fluxo da análise em três categorias 
distintas: comandos, movimento e restrição. Assim, quando uma nova macro é adicionada o usuário deve fornecer para o ambiente a informação de que categoria essa nova macro pertence, ou seja, se o usuário adicionar uma garra ao robô e quiser adicionar uma macro para mover a garra, deve-se informar a qual categoria essa macro pertence e configurar os parâmetros que a interface de inserção exige. Com essa abordagem a compilação perde um pouco em desempenho, contudo o ambiente apresenta um ganho em flexibilidade uma vez que permite que se altere os dispositivos do robô e as portas nas quais se localizam os diferentes dispositivos.

Para a implementação do ambiente de programação foi necessária uma visão macro do sistema para que os inúmeros itens incorporados fossem considerados durante a fase de análise do ambiente de programação. Isso porque a engenharia de software envolve um processo complexo de análise, planejamento e desenvolvimento de software, com o objetivo principal de manter a qualidade do produto final.

No Capítulo 3 foram descritos os componentes desenvolvidos para viabilizar as funcionalidades propostas para o sistema: o Módulo Blocos, o Editor C, o Editor Assembly e o Compilador MSPGCC para o processador MSP430 existente no robô.

Surgiram dificuldades no desenvolvimento dos botões principalmente no modo como os mesmos são manipulados, uma vez que os botões consistem de imagens encapsuladas em um componente TIMAGE. Para sanar essas questões, foram elaboradas as estratégias inserir, arrastar, excluir blocos e conectores. Ainda nesse módulo os botões foram associados a funções build-in (primitivas de software). Essa associação foi utilizada para a criação do arquivo.c a ser compilado, a partir do arquivo.blc. A estrutura do arquivo.c foi criada para conter todos os elementos necessários que obedecessem a Gramática Robô e passasse durante a compilação pelos Analisadores Léxico e Sintático. 
Os Editores C e Assembly constituem editores das respectivas linguagens de programação de alto nível e de baixo nível. Eles permitem a programação do robô por meio da utilização obrigatória da Biblioteca Padrão (primitivas de controle) do sistema. O Módulo Compilador utilizou o compilador msp430-gcc para linguagem C. Para a compilação do programa foi criado um script contendo todas as chamadas ao compilador. Esse script é chamado pela Interface Principal.

O Help é uma ferramenta de auxílio que pode ser utilizada pelo usuário, quando este possui dificuldade em achar informações no software; ou mesmo quando o software tem deficiência de informações relevantes. Neste contexto, foi desenvolvido um Help com páginas hipertexto contendo informações da interface, incluindo os módulos de programação (Blocos, C, Assembly); o módulo de visualização; tutoriais em C e Assembly, para auxiliar os usuários iniciantes ou avançados em suas pesquisas; e módulos de Controle (Teclado e Joystick). Na Figura 5.1, é mostrado o Ambiente de Programação utilizado no LRD.

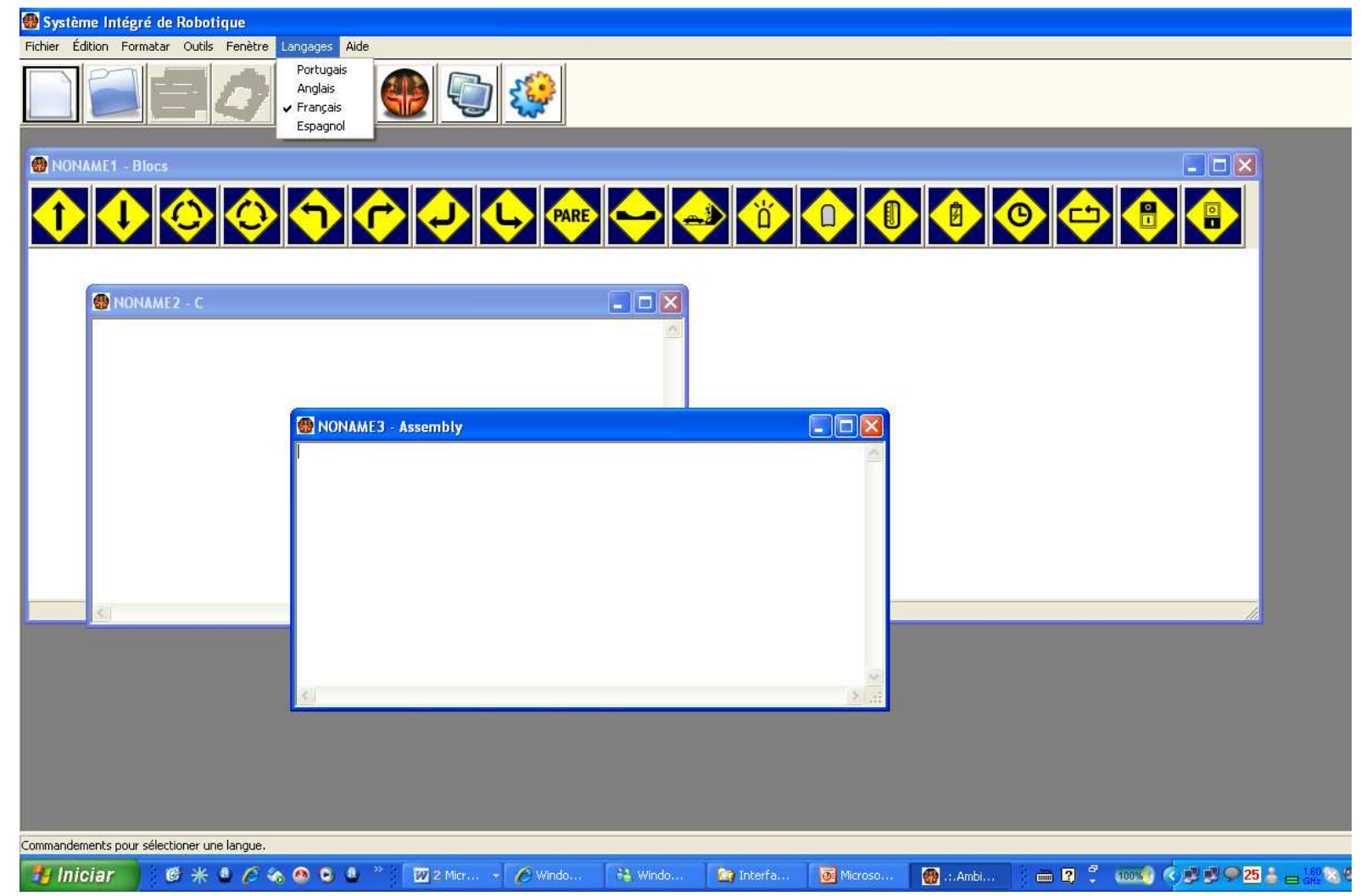

Figura 5.1 - Protótipo da Interface de Programação do LRD: interface padrão em Francês. 
Foram detectados alguns aprimoramentos que devem ser buscados como trabalhos futuros na próxima fase do projeto que são:

- Edição dos parâmetros dos blocos: o software atual já contempla os parâmetros que são fornecidos num formulário que surge assim que o usuário insere um bloco. Entretanto, uma vez criado o bloco os seus parâmetros não podem ser alterados sem que este seja excluído e substituído. Esta ferramenta de edição é uma das metas planejadas para a próxima fase do projeto.

- Modificação do conector para seta: o conector tem duas funções importantes no módulo blocos. Primeiro ele indica a sequiência lógica da programação e segundo ele é usado na estratégia de inserção de blocos. Contudo, observou-se durante a utilização do software por usuários, que dependendo da ordem e posição em que os blocos são inseridos a seqüência torna-se confusa e os conectores não informam o sentido da programação. Para solucionar esse problema os conectores serão trocados por seta.

- Inserção de blocos indicadores de laços (if, for, while): a programação em blocos está atualmente bastante limitada, porque muitos recursos importantes de programação como laços condicionais, laços de repetição e loop não foram implementados. A estrutura e a pesquisa para que esses novos blocos sejam desenvolvidos ficam sugeridos como futuros trabalhos.

- Simulador: Pesquisas já foram realizadas na busca de soluções para se desenvolver novas funcionalidades no projeto. Almeja-se desenvolver um módulo de entretenimento, o qual, entre outras ferramentas, possuirá um simulador. O simulador permitirá que o usuário faça a programação do robô e a execute remotamente em um ambiente simulado. 


\section{Referências Bibliográficas}

[1] Microsoft Robotics Studio. Disponível em <http://msdn2.microsoft.com/ptbr/robotics/default(en-us).aspx>. Acessado em jan. 2008.

[2] DUFFY, Brian R., O'HARE, Gregory M.P., BRADLEY, John F., MARTIN, Alan N. and SCHOEN, Bianca, Future Reasoning Machines: Mind \& Body, Kybernetes Volume 34, Número 9/10, pp. 1404-1420, 2005.

[3] FINKEL, Raphael A.,TAYLOR, Russell H., BOLLES, Robert C. et al. AL, a programming system for automation. Report Number: CS-TR-74-456, Institution: Stanford University, Department of Computer Science November 1974.

[4] LabVIEW, Wikipédia: a enciclopédia livre. Disponível em <http://pt.wikipedia.org/wiki/LabVIEW>. Acessado em jan. 2008.

[5] MONDADA, Francesco, FRANZI, Edoardo, IENNE, Paolo. Mobile robot miniaturisation: A tool for investigation in control algorithms. Proceedings of the 3rd International Symposium on Experimental Robotics, Kyoto, Japan, October 28-30, 1993. Springer Verlag, London, 1994, pp501-513.

[6] Robolab, Wikipédia: a enciclopédia livre. Disponível em <http://pt.wikipedia.org/wiki/Robolab>. Acessado em jan. 2008.

[7] Lego Mindstorms NXT, Wikipédia: a enciclopédia livre. Disponível em <http://pt.wikipedia.org/wiki/LEGO_Mindstorms_NXT>. Acessado em jan. 2008.

[8] Telepresence Robot Kit. Disponível no site <http:/www.terk.ri.cmu.edu/>. Acessado em jan. 2008.

[9] RobotC.net - The Language of Engineering Education. Disponível em <http://www.robotc.net/>. Acessado em jan. 2008.

[10] Carnegie Mellon Robotics Academy, Programming in ROBOTC: Fundamentals, 2007.

12] Lego Mindstorms, Wikipédia: a enciclopédia livre. Disponível em <http://pt.wikipedia.org/wiki/LEGO_Mindstorms>. Acessado em jan. 2008.

[13] Urbiforge - Universal Real-time Behavior Interface. Disponivel em <http://www.urbiforge.com/>. Acessado em jan. 2008. 
[14] ARKIN, Ronald C. Behavior-Based Robotics. MIT Press, 1998.

[15] GARCIA, Chris. Robots Enter Visible Storage. Disponível em http://edthelen.org/comp-hist/robots-core-1-4.html. Acessado em Junho de 2004.

[16] NAUR, P., RANDALL, B. Software Engineering: A report on a Conference Sponsored by the NATO Science Committee, NATO, 1969.

[17] BOOCH, G.,RUMBAUGH, J, JACOBSON I; tradução de Fábio Freitas da Silva. UML: Guia do Usuário. $4^{\text {a }}$ edição. Rio de Janeiro: Campus, 2000, p. 472.

[18] PRESSMAN, Roger S. Engenharia de Software. McGraw Hill, 5 Edição, 2002.

[19] INTRODUCTION TO KHEPERA II. Disponível em <http://www.kteam.com/robots/khepera/index.html>. Acessado em jan. 2008.

[20] D’ABREU, João Vilhete Viegas. Introdução ao Robotic Control X - RCX e Robolab. NIED/UNICAMP, 2001.

[21] YOURDON, E., Software Reuse - Application Development Strategies, vol.6, n 12, December, 1994, pp.1-16.

[22] Borland Software Corporation, BORLAND C++ Builder Developer's Guide, Versão 6, 2002.

[23] MENEZES, Paulo B. Linguagens Formais e Autômatos, 5a Edição, Sagra Luzzato, 2005.

[24] HOPCROFT, John E., ULLMAN, Jeffrey D. Introduction to automata theory, languages, and computation. Reading, Addison-Wesley, 1979.

[25] LEWIS, Harry R.; PAPADIMITRIOU, Christos H. Elementos da teoria da computação. Bookman, Porto Alegre. $2^{\text {a }}$ edição, 2000.

[26] KELLEY, D., Automata and formal languages: an introduction, Prentice-Hall, 1995.

[27] GRUNE, Dick; BAL, Henry E.; JACOBS, Ceriel J. H. Projeto Moderno de Compiladores: Implemantação a Aplicações, Campus, $1^{\text {a }}$ edição, 2002.

[28] BROGDEN, Bill; MINNICK, Chris. Guia do Desenvolvedor Java, Makron Books, $1^{\text {a }}$ edição, 2002.

[29] J.J, Neto. Introdução à Compilação. Livros Técnicos e Científicos, Editora S.A., 
1987.

[30] KOWALTOWSKI, T.; LUCCHESI, Claudio L.; STOLFI, J. Application of finite automata in debugging natural language vocabularies. In First South American String Processing Workshop, Belo Horizonte, Brasil, 1993.

[31] AHMED, S.; HOMA, J. Multiple User Interfaces: Cross-Platform Applications and Context-Aware Interfaces, ed. John Wiley \& Sons, pp. 448.

[32] BORLAND BRASIL. Disponível em http://www.borland.com.br/. Acessado em Junho de 2004.

[33] LARMAN, Craig, Utilizando UML e Padrões: uma introdução à analise e ao projeto orientados a objetos e ao desenvolvimento iterativo, $3^{\mathrm{a}}$ edição, Bookman, 2007.

[34] ABBOT, R. Program Design by Informal English Descriptions. Communications of the ACM, vol. 26(11), 1983.

[35] SOUPHAVANH, Anousak, KAROONBOONYANAN, Theppitak. Free/Open Source Software: Localization. $1^{\mathrm{a}}$.edição. EUA.: United Nations Development ProgrammeAsia Pacific Development Information Programme - (UNDP-APDIP), 2005, pp. 58.

[36] Dr. International (Microsoft). Developing International Software, Microsoft Press, $2^{\mathrm{a}}$ edição, 2002.

[37] JOANN T., PhD Hackos, REDISH, Janice C. User and Task Analysis for Interface Design, Wiley, 1 edition, 1998.

[38] Multiple Document Interface. Disponível em http://msdn2.microsoft.com/enus/library/ms632591(VS.85).aspx. Acessado em jan. 2008.

[39] AHO, Alfred V., SETHI, Ravi, ULlMAN, Jeffrey D. Compilers: Principles,

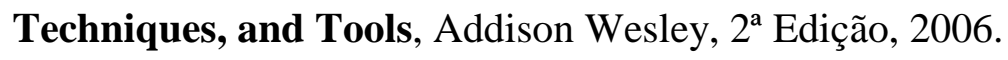

[40] Compra de robôs no Brasil fica abaixo da média mundial. Disponível em <http://www.bbc.co.uk/portuguese/reporterbbc/story/2004/10/041020_robomp.shtml>. Acessado em jan. 2008.

[41] Robótica. Disponível em <http://www.roboticalivre.org>. Acessado em jan. 2008.

[42] Não só os carros são feitos por robôs. Disponível em <http://www.abb.com.br/cawp/brabb155/8866b37e2c01f93903256eb5005d8410.aspx>. 
Acessado em jan. 2008.

[43] Microprocessadores MSP430. Disponível em <www.ti.com/>. Acessado em jan. 2008.

[44] CASTILHO, Maria Inês. Robótica na Educação: Com que objetivos?. Monografia de Conclusão, Pós-Graduação em Informática na Educação, Universidade Federal do Rio Grande do Sul, 2002. 